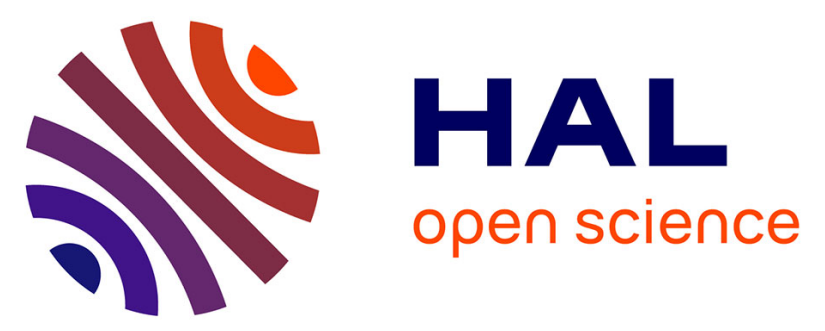

\title{
Pliocene and Late Pleistocene actinopterygian fishes from Santa Maria Island, Azores (NE Atlantic Ocean): palaeoecological and palaeobiogeographical implications
}

Sérgio Ávila, José M.N. Azevedo, Patrícia Madeira, Ricardo Cordeiro, Carlos Melo, Lara Baptista, Paulo Torres, Markes Johnson, Romain Vullo

\section{To cite this version:}

Sérgio Ávila, José M.N. Azevedo, Patrícia Madeira, Ricardo Cordeiro, Carlos Melo, et al.. Pliocene and Late Pleistocene actinopterygian fishes from Santa Maria Island, Azores (NE Atlantic Ocean): palaeoecological and palaeobiogeographical implications. Geological Magazine, 2020, 157 (9), pp.15261542. 10.1017/S0016756820000035 . insu-02958955

\section{HAL Id: insu-02958955}

\section{https://hal-insu.archives-ouvertes.fr/insu-02958955}

Submitted on 14 Dec 2020

HAL is a multi-disciplinary open access archive for the deposit and dissemination of scientific research documents, whether they are published or not. The documents may come from teaching and research institutions in France or abroad, or from public or private research centers.
L'archive ouverte pluridisciplinaire HAL, est destinée au dépôt et à la diffusion de documents scientifiques de niveau recherche, publiés ou non, émanant des établissements d'enseignement et de recherche français ou étrangers, des laboratoires publics ou privés. 
1 Plio-Pleistocene actinopterygian fishes from Santa Maria Island (Azores:

2 North-eastern Atlantic Ocean): palaeoecological and

3 palaeobiogeographical implications

4

5 SÉRGIO P. ÁVILA*,1,2,3, JOSÉ M.N. AZEVEDO ${ }^{2,4}$, PATRÍCIA MADEIRA ${ }^{1,2,3}$, RICARDO

6 CORDEIRO ${ }^{1,2,3}$, CARLOS S. MELO ${ }^{1,3,5,6}$, LARA BAPTISTA $^{1,2,3}$, PAULO TORRES ${ }^{1,2,3}$, MARKES

7 E. JOHNSON ${ }^{7}$ \& ROMAIN VULLO ${ }^{8}$

$8 \quad{ }^{1} \mathrm{CIBIO}$, Centro de Investigação em Biodiversidade e Recursos Genéticos, InBIO

9 Laboratório Associado, Pólo dos Açores, Azores, Portugal. 'Departamento de Biologia,

10 Faculdade de Ciências e Tecnologia da Universidade dos Açores, 9501-801 Ponta

11 Delgada, Açores, Portugal. ${ }^{3}$ MPB-Marine PalaeoBiogeography working group of the

12 University of the Azores, Rua da Mãe de Deus, 9501-801 Ponta Delgada, Açores,

13 Portugal. ${ }^{4}$ Grupo de Biodiversidade dos Açores and CE3C - Centro de Ecologia, Evolução

14 e Alterações Ambientais, Portugal. ${ }^{5}$ Departamento de Geologia, Faculdade de Ciências,

15 Universidade de Lisboa, 1749-016 Lisboa, Portugal. ${ }^{6}$ Instituto Dom Luiz, Faculdade de

16 Ciências, Universidade de Lisboa, 1746-016 Lisboa, Portugal. ${ }^{7}$ Department of

17 Geosciences, Williams College, Williamstown, Massachusetts 01267, USA. ${ }^{8}$ Univ

18 Rennes, CNRS, Géosciences Rennes, UMR 6118, 35000 Rennes, France.

19 Correspondence and request for materials should be addressed to S.P.A. (email:

20 avila@uac.pt) 


\section{Abstract}

25 Fossil fish are among the rarest in volcanic oceanic islands, their presence providing

26 invaluable data for the understanding of more general (palaeo)biogeographical

27 patterns and processes. Santa Maria Island (Azores Archipelago) is renowned for its

28 palaeontological heritage, with representatives of several phyla, including the

29 Chordata. Herein, we report on the fossil fishes, resulting in an increase of the number

30 of Pliocene fish from the Azores to 11 taxa: 7 Chondrichthyes and 4 Actinopterygii. The

31 genus Sparisoma is reported for the first time in the fossil record. The presence of

32 fossil remains of the parrotfish Sparisoma cretense in Last Interglacial outcrops is

33 significant, because it posits a setback for the theory that most of the present-day

34 Azorean marine species colonized the area after the last glacial episode. Our

35 multidisciplinary approach combines palaeontological data with ecological and

36 published genetic data, offering an alternative interpretation. We suggest that most of

37 the Azorean shallow-water subtropical and temperate marine species living in the

38 archipelago during the Last Interglacial were not affected by the decrease in sea

39 surface temperatures during the last glacial episode. We also predict low genetic

40 diversity for fish species presently living in the Azores and ecologically associated with

41 fine sediments. These are viewed as post-glacial colonizers or as 'bottleneck' survivors

42 from the Last Glaciation.

44 Keywords

45 Actinopterygii; Azores archipelago; glacial-interglacial cycles; sea-surface temperature;

46 Sparisoma cretense; Labrodon pavimentatum; Sparidae 
49 Oceanic islands have long been considered as ideal places to study biogeographical

50 patterns and processes, and to test evolutionary theories (Darwin, 1859; Wallace, 1880). A detailed knowledge of an island's geological history and evolution is of paramount importance, influenced by the ontogenic state of the island as determined by a series of factors [e.g. geological age of the oldest subaerial lavas, terrestrial area, maximum altitude, latitude; see Whittaker et al. (2010); Fernández-Palacios et al. (2016)]. Such factors ultimately regulate and explain both the number of species that live on the island, as well as the functional composition of the biological assemblage itself. The marine fossil record for volcanic oceanic islands may be considered as rare or poor, especially when compared to that for vastly larger continentes (Ávila et al., 2018). However, the dating of an island's fossil fauna and flora when coupled with checklists validated by experts provides valuable insights for a number of disciplines such as palaeobiogeography, palaeoceanography, phylogenetic and climate-change studies (Ávila et al., 2019). The remarkable marine fossil record of Santa Maria Island in the Azores Archipelago has been intensively studied over the last decades (for a review, see Ávila et al. (2018) and references therein). The result has been 204 Pliocene and 146

66 Pleistocene (Last Interglacial) species and 15-20 further ichnospecies reported for the island (Santos et al., 2015; Uchman et al., 2016, 2017; Raposo et al., 2018). The vast 68 majority of specimens collected are invertebrates: molluscs (Zbyszewski \& Ferreira, 1962; Ávila et al., 2002, 2015a, 2015b, 2016; Janssen et al., 2008), brachiopods (Kroh et al., 2008), crustacean balanids (Winkelmann et al., 2010), echinoderms (Madeira et al., 2011) and ostracods (Meireles et al., 2012). A small number of fossil vertebrate 
remains also have been studied, most notably cetaceans (Estevens \& Ávila, 2007; Ávila et al., 2015c) and sharks (Ávila et al., 2012). Fossil bony fishes are known from the island, but the last account for Santa Maria fossil Actinopterygii fishes' dates from the 1950's and 60's (Zbyszewski \& Ferreira, 1962; Ferreira, 1955). With few exceptions (Ávila et al., 2012; Betancort et al., 2016), the majority of the published palaeoecological and palaeobiogeographical studies on the marine fauna and flora of the Macaronesian archipelagos targeted sessile or low-motility species, such as the marine molluscs, echinoderms, bryozoans, barnacles, ostracods and algae (Meco, 1977; Meco et al., 1997, 2015, 2016; Ávila et al., 2008a, 2008b, 2009; 2015a;

Winkelmann et al., 2010; Madeira et al., 2011; Santos et al., 2011, 2012a, 2012b; Meireles et al., 2012; Ávila et al., 2013; Baarli et al., 2013, 2017; Betancort et al., 2014; Johnson et al., 2014; Meireles et al., 2014; Rebelo et al., 2014; Tuya et al., 2017). Still largely unresolved, an interesting question is how the evolutionary patterns and processes inferred from these studies do relate with species' dispersal capabilities (Ávila et al., 2019). Therefore, this study aims to: 1) review and update the status of all existing Actinopterygii fossil material from Santa Maria Island; 2) use this new data to test previous statements by several authors (e.g., Briggs, 1974; Santos et al., 1995; Domingues et al., 2006, 2008) who concluded that the shallow littoral fauna of the

90 Azores was extirpated during the Last Glacial episode; and 3) compare the palaeobiogeographical and palaeoecological patterns known from sessile and low-

92 dispersive species (e.g. non-planktotrophic marine molluscs), with that of highly motile 93 species such as fishes. 
97 The nine volcanic oceanic islands that form the Azores Archipelago are located in the

98 north-eastern Atlantic Ocean (Fig. 1) and rise from a bathymetric anomaly (the Azores

99 Plateau) with depths of about 2,000 m. The most distant islands (Flores, in the western

100 group, and Santa Maria in the eastern group) are $615 \mathrm{~km}$ apart. Flores and Corvo

101 belong to the North American tectonic plate, whereas the other seven islands are

102 located around the most-studied area called the Azores Triple Junction (Laughton \&

103 Whitmarsh, 1974), a place where three major tectonic plates, North American, Nubian

104 and Eurasian, interact. The Azores Triple Junction is limited by the East Azores Fracture

105 Zone to the south, the Mid-Atlantic Ridge (MAR) to the west and the Terceira's Rift and

106 Gloria Fault to the northeast and east (Searle, 1980) (Fig. 1A). This area (i.e. the Azores

107 Plateau, the Azores Triple Junction and the islands that compose the Azores

108 Archipelago), was named the 'Azores Geosyndrome' (Vogt \& Jung, 2018), which is

109 derived from a series of anomalies related to 'crustal thickness, rock composition,

110 basement depth, plate boundary morphology, seismicity, gravity and geoid, and upper

111 mantle seismic velocity structure'.

\section{Santa Maria Island}

114 This island has a complex geological history (see Ramalho et al. (2017) for a review). It

115 is the oldest island of the Azores Archipelago, first rising above sea level at about $6 \mathrm{Ma}$,

116 initially by Surtseyan activity (the Cabrestantes Formation), and then by subaerial,

117 monogenetic volcanism associated to the Porto Formation. High rates of magma

118 production formed a shield volcano (the Anjos volcanic complex, dating from 5.8 to 5.3

$119 \mathrm{Ma})$, which substantially increased the area of the Santa Maria protoisland, as attested 
120 by the present-day insular shelf (Ricchi et al., 2018). Although the entire volcanic

121 edifice likely has undergone subsidence since extrusion of the first lavas of the

122 submarine edifice, at around 5.3 Ma, a prolonged subsidence rate of about $100 \mathrm{~m} / \mathrm{myr}$

123 lasted until 3.5 Ma (Ramalho et al., 2017). Volcanic activity associated with the Anjos

124 shield volcano ceased at about 5.3 Ma and was followed by a period of about $1.2 \mathrm{myr}$

125 with almost no volcanism, during which the protoisland nearly vanished due to erosion

126 (Ávila et al., 2012; Ramalho et al., 2017), thus originating a large, flat, shallow

127 seamount. The sediments of this unit (the Touril volcano-sedimentary complex, 5.30 to

$1284.13 \mathrm{Ma}$ ) are highly fossiliferous and correspond to early Pliocene outcrops formerly

129 described in the literature as of Miocene in age (see Madeira et al. (2007) for a

130 review). Volcanic activity initiated again at about 4.1 Ma, during the first rejuvenated

131 stage, with eruptive foci associated with the Pico Alto volcanic successions, first

132 submarine and later subaerial in nature (Ramalho et al., 2017), thus originating the

133 revival of Santa Maria as an island. This stage lasted to $3.5 \mathrm{Ma}$, when the subsidence

134 trend was reversed, and the island's volcanic edifice initiated an uplift trend continuing

135 to the present day. Initially, a rate of $59 \mathrm{~m} / \mathrm{myr}$ occurred from 3.5 to $2.15 \mathrm{Ma}$,

136 thereafter at a slower rate of $42 \mathrm{~m} / \mathrm{myr}$ between $2.15 \mathrm{Ma}$ and the present (Ricchi et

137 al., 2018). This uplift trend, coupled with Pleistocene glacio-eustatic sea-level

138 fluctuations, produced a staircase of 10 subaerial and of 5 submerged marine terraces,

139 the former particularly evident across the island's western sector at elevations ranging

140 from $7-11$ to $210-230 \mathrm{~m}$ (Ramalho et al., 2017), and the latter on the shelf all around

141 the island at depths ranging between $-40 /-50$ and $-120 /-140 \mathrm{~m}$ (Ricchi et al., 2018). A

142 second rejuvenated stage occurred from 3.2 to $2.8 \mathrm{Ma}$, associated with monogenetic

143 volcanism of the Feteiras Formation. Uplift has continued until today, but erosion 
144 became the dominant agent impacting the island's landscape during the last 2.8 myr

145 (Ramalho et al., 2017).

146

147 Institutional Abbreviations

148 DBUA-F: fossil collection of the Department of Biology of the University of the Azores 149 (Portugal).

150 LAQ-F: fossil collection of the Liceu Antero de Quental, Ponta Delgada, São Miguel Island 151 (Azores, Portugal).

152 MGM: fossil collection of the former Museu Geológico e Mineiro, now Museu Geológico, 153 LNEG, Lisbon (Portugal).

\section{Methods}

Most of the 20 known fossiliferous outcrops on Santa Maria Island are early Pliocene in

157 age, but scattered Last Interglacial deposits from the Pleistocene also are known from

158 the north (Lagoinhas; Ávila et al., 2009a, 2009b) and southern shores (Prainha, Praia

159 do Calhau and Vinha Velha outcrops (Ávila et al., 2002, 2015a; Fig. 1B). The fossil fish

160 specimens reported, herein, were found in sedimentary layers from a total of eight

161 outcrops (cf. Table 1). Six of these contain fauna that deposited during the early

162 Pliocene: Cré (Kroh et al., 2008; Fig. 2A), Figueiral (Rebelo et al., 2016a; Ávila et al., 163 2018a; Fig. 2B), Malbusca (Rebelo et al., 2016b; Johnson et al., 2017; Fig. 3A), West

164 Fault of Malbusca (Uchman et al., 2017 Fig. 3B), Pedra-que-pica (Ávila et al., 2015b,

165 2018a; Uchman et al., 2016; Fig. 3C), and the yet undescribed Ponta dos Frades

166 outcrop. The two remaining outcrops [Prainha (Fig. 2C) and Vinha Velha (Fig. 2D)]

167 include faunas from the Last Interglacial period (c. 116-130 kyr), of which the warmest 
168 interval is known as MIS 5e (Marine Isotopic Stage 5e) (Ávila et al., 2015a). Figure 1B

169 shows the geographical location of each outcrop and Figure 4 displays representative

170 composite sections of the studied outcrops.

All specimens described were collected during fourteen fieldwork campaigns of

172 the Palaeontology in Atlantic Islands workshops, held on Santa Maria Island from 2002

173 to 2017. In compliance with the legislation that rules the "PalaeoPark Santa Maria", all

174 fossil specimens collected were deposited in the fossil collection at the Department of

175 Biology of the University of the Azores (DBUA-F). Over 1,300 lots containing fossil

176 specimens collected at Santa Maria Island were screened for fossil Actinopterygii

177 fishes, yielding a total of 42 lots. Systematics for Actinopterygii conform to the World

178 Register of Marine Species (WoRMS, 2018). As the oral and pharyngeal tooth plates

179 are frequently well preserved in the fossil record and as they display diagnostic

180 features (Bellwood \& Schultz, 1991), direct comparisons of the fossil remains with

181 fossil and recent remains (whenever available) were used to classify our material. The

182 teeth terminology for Scaridae is in accordance with Day (2002).

183 All data generated or analysed during this study are included in this published

184 article.

185

186

187 Results

188 Actinopterygian fish taxa were found in the fossilliferous sediments of Santa Maria

189 Island: at least two extinct Sparidae species with a probable Mio-Pliocene temporal

190 range (Fig. 5A-Q); Sparisoma cretense (Linnaeus, 1758) (Fig. 6), an extant Scaridae

191 herein reported for the Pliocene and Pleistocene (Last Interglacial, MIS 5e) of the 
192 Azores; and Labrodon pavimentatum Gervais, 1857 (Fig. 7), an extinct Labridae with a

193 Mio-Pliocene temporal range. In total, 54 teeth and several pharyngeal plates were

194 found.

195

196

SYSTEMATIC PALAEONTOLOGY

197

198

Class ACTINOPTERYGII Klein, 1885

199

Order PERCIFORMES Bleeker 1859

200

Family SPARIDAE Rafinesque, 1818

201

Genus and species indet.

202

203

Figure $5 \mathrm{~A}-\mathrm{Q}$

204 Material Examined-54 teeth in total: Pedra-que-pica (26 teeth), Malbusca (17), Cré (4),

205 West Fault of Malbusca (2), Figueiral (1): DBUA-F 165-1, 165-2, 204-2, 205-2, 250-1, 260, $286,313,344-2,350,382,448,460-1,477-2,508-1,508-2,595,596,597,598,599,601$, $647,667,668,669,671,672,673,674,966-2,991,1014,1017,1073,1083$. Cré, formerly also known as Pedreira dos Frades (2): MGM 11311, 11312 (one spheroidal and one oval

209 molariform teeth, respectively); Santa Maria Island (4 teeth), no locality: MGM 11313.

210 Description-The 50 teeth examined from the DBUA collection represent three types of

211 dentition: molariform, conical and incisiform teeth. We have examined a total of 39

212 molariform teeth, corresponding to the lingual series (36 spheroidal in shape (Fig. 5A-F,

$2135 \mathrm{~L})$, ranging from 2.87 to $17.34 \mathrm{~mm}$ in diameter; and 3 oval in shape, $5.89-11.51 \mathrm{~mm}$ ),

2149 conical teeth (Fig. 5G-K), corresponding to the labial series (2.41-7.93 $\mathrm{mm}$ in diameter)

215 and 2 'spatulate' incisiform teeth (1.45-1.53 mm in diameter; DBUA-F 668, 671). Some 
216 of the largest spheroidal molariform teeth exhibit a central depression; these are

217 considered to belong to the upper lingual series (Fig. 5A-C, 5F). Some of the largest teeth

218 show radial grooves at the base of the crown. The general shape and size resemble some

219 of the teeth described by (Betancort et al., 2016).

220 The four teeth housed at MGM (Lisbon) that we examined are all lateral teeth, with a 221 conical shape, and rounded, worn crowns (Fig. 5M-Q).

222 Remarks - this material represents at least two taxa, including a small one and a larger one (possibly Diplodus and Pagrus, respectively). Some of these teeth might also belong to Archosargus (Cutwa \& Turingan, 2000). However, any generic/specific assignment would be highly tentative without any additional osteological evidence.

Stratigraphic and geographic range-Extinct Archosargus species are reported from the Miocene and Pliocene of the Mediterranean Sea (Obrador \& Mercadal, 1973; Vicens \& Rodríguez-Perea, 2003; Mas \& Antunes, 2008) and from the Miocene of France (Gagnaison, 2017). In the Atlantic, Archosargus species are reported from the Miocene of Portugal (Zbyszewski \& Moitinho d'Almeida, 1950; Jonet et al., 1975) and Morocco

231 (Lecointre, 1952), the Pliocene of Canary Islands (Gran Canaria Island) (Betancort et al., 2016) and from the Pliocene of the Azores (Santa Maria Island) (Zbyszewski \& Moitinho d'Almeida, 1950; Ferreira, 1955; Zbyszewski \& Ferreira, 1962; Ávila et al., 2015b). The extinct species formerly known as $D$. jomnitanus is reported from the Miocene of France (Gagnaison, 2017), Portugal (Zbyszewski \& Moitinho d'Almeida, 1950; Jonet et al., 1975) and the Mediterranean Sea (Vicens \& Rodríguez-Perea, 2003), and from the Pliocene of

237 the Azores (Santa Maria Island) (Zbyszewski \& Moitinho d'Almeida, 1950; Ferreira, 1955;

238 Zbyszewski \& Ferreira, 1962). Extinct Pagrus species are reported from Mio-Pliocene 
sediments from the Mediterranean Sea and from Europe (Arambourg, 1927; Bauzá, 1948; Menesini, 1969; Bauzá \& Plans, 1973; Jonet, 1975; Antunes et al., 1981).

Family LABRIDAE Cuvier, 1816

Tribe SCARINI Rafinesque, 1810

Genus SPARISOMA Swainson, 1839

Sparisoma cretense (Linnaeus, 1758)

Figure 6

Material Examined-Seven pharyngeal plates (4 lower and 3 upper) plus one fragmentary tooth plate: Ponta dos Frades (3 lower and 3 upper pharyngeal plates), Vinha Velha (1 lower pharyngeal plate) and Pedra-que-pica (one fragmentary tooth plate): DBUA-F $825,1030,1069,1214-1$ to $1214-5$.

Description-This species has a jaw formed from modified hindmost gill-arch, with tooth-bearing bones above, denominated upper pharyngeal plates, and a large, single bone below, the lower pharyngeal plate. Our fossil specimens' pharyngeal plates are very similar to those of Recent specimens of Sparisoma cretense. The tooth rows of the lower pharyngeal plate range from 11 to 12 in the fossil material, and from 10 to 14 in the recent material. As all fossil lower pharyngeal plates examined are smaller than the recent ones (see below), we attribute the intraspecific variation of the pharyngeal jaw elements (i.e., the lower number of tooth rows in the fossil material, as well as the slightly different angles of the lateral bony articulation in smaller fossil specimens) to ontogeny. A fresh specimen of S. cretense was weighted and measured (1.585 kg; 45.50 $\mathrm{cm}$ in total length; $40.50 \mathrm{~cm}$ standard length). Its lower pharyngeal plate was $4.11 \mathrm{~cm}$ wide, which compares with those from fossil material, which measured $2.62 \mathrm{~cm}$ wide 
264 (DBUA-F 1030), $2.82 \mathrm{~cm}$ (DBUA-F 1214-1), $2.84 \mathrm{~cm}$ (DBUA-F 1214-2) and an inferred 3.82

$265 \mathrm{~cm}$ (DBUA-F 825 broken specimen measuring $2.84 \mathrm{~cm}$ ). The fragmentary tooth plate

266 collected at Pedra-que-pica (DBUA-F 1069) measures $1.22 \mathrm{~cm}$.

267 Today, there are 15 species of Sparisoma in the Atlantic Ocean and the Mediterranean

268 Sea (Table 2). Of these, only 3 species are reported for the Eastern Atlantic: two tropical 269 species (Sparisoma choati Rocha, Brito \& Robertson, 2012, reported for Cabo Verde, São

270 Tomé and Príncipe and to the tropical west African shores; S. frondosum (Agassiz, 1831),

271 endemic to Cabo Verde); and the eurythermic S. cretense, with a wider geographical

272 distribution, occurring in all the Macaronesian archipelagos, the Mediterranean Sea,

273 Iberian shores and Senegal (Abecasis et al., 2008; Randall, 1990).

274 Ecology-The parrotfish Sparisoma cretense is an omnivorous daytime feeder species

275 with specialized pharyngeal bones and muscles (Bullock \& Monod, 1997). It is a sexually

276 dimorphic species that lives on rocky bottoms covered by algae and sea grass beds,

277 where it feeds on algae, sea grass and small invertebrates with its fused, beak-like jaw

278 (Quignard \& Pras, 1986; Abecasis et al., 2008). This shallow-water species is common to

279 about $50 \mathrm{~m}$ depth (Guidetti \& Boero, 2002).

280 Stratigraphic and geographic range-This extant species is presently reported from the

281 Mediterranean Sea and from the eastern Atlantic shores of Portugal, the Azores,

282 Madeira, Canary Islands, Cabo Verde and Senegal (Abecasis et al., 2008; Randall, 1990).

283 A search for fossil Sparisoma species on the PaleoBiology Database and on Bellwood et

284 al. (2019) yielded no occurrences. With the exception of otolithes from the Late Eocene

285 of France referred to Sparisoma [Nolf (1988) but see remarks by Bellwood et al. (2019),

286 in whose opinion these otoliths are not secure evidence of Sparisoma], this genus is

287 reported herein for the first time from the fossil record based on dental remains. S. 
cretense is herein reported from the Pliocene (Pedra-que-pica and Ponta dos Frades outcrops) and Pleistocene (Vinha Velha outcrop; Last Interglacial, MIS 5e) of Santa Maria

290 Island, Azores.

291

292

293

294

295

296

297

298

299

300

301

302

303

304

305

306

307

308

309

310

311
Tribe HYPSIGENYINI Günther, 1861

Genus LABRODON Gervais, 1857

† Labrodon pavimentatum Gervais, 1857

Figure 7

Material Examined-Two lower pharyngeal plates, both from Pedra-que-pica outcrop

(Fig. 7A-E): DBUA-F 386, 678. One lower pharyngeal plate from Santa Maria Island (no locality; Fig. 7F-G): MGM 11318.

Description-The dentition of Labridae is characterized by subtriangular pharyngeal plates composed by small, contiguous, flattened teeth, which may be rounded or suboval in shape (Jonet, 1968). The two lower pharyngeal plates collected from the Pedraque-pica coquina in Santa Maria Island (Azores), as well as that deposited at MGM collection (Lisbon), conform with both the figures and the description provided by Betancort et al. (2016). Cocchi (1864) was the first to describe pharyngeal plates similar to our samples, which were attributed to Labrodon multidens (Sacco, 1916), and to $L$. pavimentatum (Simonelli, 1889).

Stratigraphic and geographic range-This extinct species is reported from the Miocene of France (Sauvage, 1875; Gagnaison, 2017), Portugal (Jonet et al., 1975), Poland (Bellwood et al., 2019), and the Mediterranean (Cocchi, 1864; Mas \& Antunes, 2008). It is also reported from the western Atlantic, from the Miocene of Costa Rica (Laurito et al., 2014) and also from the Pliocene of Morocco (Lecointre, 1952), France (de Lumley, 
312 1988) and the Azores (Santa Maria Island: Zbyszewski \& Moitinho d'Almeida, 1950;

313 Ferreira, 1955; Zbyszewski \& Ferreira, 1962; this work).

316 Discussion

317 During the late Miocene, the once continuous and large tropical Miocene European-

318 West African palaeobiogeographical molluscan province (Ávila et al., 2016) stretched

319 between about $50^{\circ} \mathrm{N}$ to the equator and further south to Angola (Baarli et al., 2017),

320 at about $15^{\circ} \mathrm{S}$ (Fig. 8A). The waters around the Azores thus exhibited tropical

321 temperatures during the late Miocene/early Pliocene, with mean annual sea surface

322 temperatures (SSTs) estimated to be about $3.7-6.3^{\circ} \mathrm{C}$ higher than the present-day

$32320.6^{\circ} \mathrm{C}$ (Ávila et al., 2016). The extinct Pliocene fish species reported from the

324 fossiliferous sediments of Santa Maria Island in the Azores (two Sparidae indet. and

325 Labrodon pavimentatum) add at least three more taxa to an increasing number of

326 known thermophilic taxa that went extinct or locally disappeared from this volcanic

327 oceanic island (as well as from other Atlantic islands/archipelagos) during the

328 pronounced climatic cooling events that characterized the mid-Piacenzian stage,

329 towards the end of the Pliocene at about 3.3-3.6 Ma (or sometime prior),

330 consequence of a global glaciation (the MIS M2; see Lisiecki \& Raymo, 2005; Fig 8B).

331 Several warm-water species are also known to have disappeared from the Canary

332 Islands at about 4.2-4.1Ma (Meco et al., 2007). As a direct consequence of the MIS M2

333 glaciation, a southward geographical range contraction of the biogeographical

334 provinces took place (Ávila et al., 2016; Fig. 8B). Table 3 lists examples of several

335 extinctions or extirpations of Pliocene species from the marine fauna of Santa Maria 
Island across a wide spectrum of phyla: molluscs ( 5 bivalves, 1 benthic

macrogastropod, 1 neustonic gastropod and 4 holoplanktonic gastropods; Janssen et al., 2008; Beu, 2017; Ávila et al., 2015, 2016, 2018a), 4 echinoderms (Madeira et al., 2011), 1 brachiopod (Kroh et al., 2008), 1 barnacle (Winkelmann et al., 2010) and 5

340 sharks (Ávila et al., 2012). This pattern of extinctions/extirpations from volcanic oceanic islands during the late Pliocene also is reported for other Atlantic archipelagos, such as Madeira (Santos et al., 2012), Canary Islands (Meco et al., 2007, 2015, 2016; Baarli et al., 2017) and Cabo Verde (Baarli et al., 2017). destroyed, originating a large seamount where marine sediments rich in organic debris were deposited. In a broader palaeoceanographical context, the pattern of sea surface and bottom circulation in the area should have been different from the present day, as the connection between the Atlantic and the Pacific oceans was still open at the

349 Central American Seaway (Garcia-Castellanos et al., 2009), and the Gibraltar Seaway had just reopened at $5.33 \mathrm{Ma}$, in an event known as the Zanclean or post-Messinian flood (Blanc, 2002). As attested by the fossil record of their geographical distribution, most of the Actinopterygii (this work) and Chondrichthyes fishes (Ávila et al., 2012) reported from the Pliocene of the Azores are also reported from Pliocene deposits in the northeast Atlantic and the Mediterranean Sea, with some species being reported as well from Pliocene sediments along the north-western shores of Africa, and no

356 Western Atlantic species reported. This predominantly eastern Atlantic pattern of 357 biogeographical relationships for the Azorean Pliocene marine fauna derives from the 358 sea surface currents set in place by the easterly trade winds that facilitated dispersal of marine species from European shores towards the western Atlantic, a few reaching 
and colonizing American Atlantic shores (Harzhauser et al., 2002; Baarli et al., 2017) and even the Pacific (Meco et al., 2016).

The final closure of the Central American Seaway, caused by re-emergence of the Panamanian land bridge (Briggs, 1995) at about 2.8 Ma (O'Dea et al., 2016), and the associated strengthening of the Gulf Stream, altered the north Atlantic system of sea surface circulation. The effect of a stronger Gulf Stream is testified by the shallowwater ( $<50 \mathrm{~m}$ depth) marine molluscs of the Azores, which show a gradual increase in the number of Western-Atlantic related species from $10.0 \%$ to $12.3 \%$, when Last Interglacial (MIS 5e) checklists of fossil marine molluscs from the Azores (Ávila et al., $2002,2009 a, 2009 b, 2015 a)$ are compared to recent checklists available from this archipelago (Ávila, 2000; Cordeiro et al., 2015; Fig. 8C). Intensification of the Pleistocene glacial episodes clearly impacted the Azorean fish pool in a similar manner to that described for the marine molluscs (Ávila et al., 2008a, 2008b, 2009a). We here expand on those conclusions, which were based on the MIS 5e mollusc fossil record from Santa Maria Island, and we postulate that range expansions of tropical and subtropical fishes with a Cabo Verdean origin probably occurred during 'windows of opportunity' towards the end of glacial Terminations (i.e.

377 the short periods of time, c. $6 \mathrm{kyr}$, between the end of a glacial episode and the inception of a full interglacial episode). During those intervals, some fish species might have been able to reach, colonize and establish viable populations in the Canaries,

380 Madeira and, in less numbers, the Azores Archipelago (Fig. 8D). We further

381 hypothesize that, again in a similar manner to the marine molluscs (Ávila et al., 2008a, 382 2008b, 2009a), during the subsequent glacial episode, (1) all tropical species with a 383 Cabo Verdean provenience that became established in the northern archipelagos 
384 (Azores, Madeira and Canaries) during the previous interglacial were extirpated (Ávila

385 et al., 2019; Fig. 8E), and (2) shallow-water fish species associated with fine sediments

386 were functionally extirpated (i.e. locally disappeared from most volcanic oceanic

387 islands) or their insular populations passed through a 'bottleneck' effect, resulting in a

388 substantial net decrease in population size. The latter event occurs because the fine-

389 sand habitat is mostly lost whenever sea level falls below the erosive edge of the

390 insular shelf during glacial episodes (Ávila et al., 2008b, 2015a; Fig. 8G-I). The trigger

391 for this outcome resides with the slope of the insular volcanic edifice being so steep

392 below the erosive shelf edge, that it no longer becomes possible to physically retain

393 fine sediments around the island, ultimately being lost to the abyssal depths (Fig. $8 \mathrm{H}$ ).

394 Either way, be it post-glacial colonizers or 'bottleneck' glacial survivors, we predict

395 lower genetic diversity of the populations of shallow-water insular fish species

396 associated with sandy bottoms [e.g. the following extant species in the Azores: the

397 European finless eel Apterichtus caecus (Linnaeus, 1758); the wide-eyed flounder

398 Bothus podas (Delaroche, 1809); the striped red mullet Mullus surmuletus Linnaeus,

399 1758; the Atlantic lizard fish Synodus saurus (Linnaeus, 1758); the greater weever

400 Trachinus draco Linnaeus, 1758; and the pearly razorfish Xyrichtys novacula (Linnaeus,

401 1758)], when compared with continental populations. This prediction can be tested

402 using molecular tools.

403 In contrast, fish species associated with algae-covered rocky shores, such as the

404 omnivorous parrotfish Sparisoma cretense, were not affected by the drop in SSTs

405 associated with the inception of glacial episodes, which was estimated at about $2-3^{\circ} \mathrm{C}$

406 (Crowley, 1981) in the region of the Azores. The lineage that led to the two eastern

407 Atlantic species, S. cretense (presently reported from the Mediterranean Sea and from 
the eastern Atlantic shores of mainland Portugal, the Azores, Madeira, Canaries, Cabo

409 Verde and Senegal; cf. Table 2), and S. strigatum (Günther, 1862) (endemic to Saint

410 Helena and Ascension islands; Table 2), originated at about $10 \mathrm{Ma}$ from a West Atlantic

411 ancestor (Bernardi et al., 2000). The oldest known fossil specimens of S. cretense were

412 collected in two Pliocene outcrops from Santa Maria Island (Pedra-que-pica and Ponta

413 dos Frades) and dated as $4.78 \pm 0.13$ to $4.13 \pm 0.19$ myr in age (Table 1 ), thus our data

414 are in agreement with the estimates of Bernardi and colleagues (2000).

415 Last interglacial (MIS 5e) fossils of S. cretense were also collected from a

416 Pleistocene outcrop (Vinha Velha; cf. Table 1). Today, S. cretense lives as far north as

417 the eastern Atlantic shores of mainland Portugal, where it breeds during the summer,

418 from July to September (Abecasis et al., 2008; Froese \& Pauly, 2018), with mean SSTs

419 varying from 17 to $19^{\circ} \mathrm{C}$. The present average SSTs range in the Azores from $15^{\circ} \mathrm{C}$ in

420 the winter, to about $23-24^{\circ} \mathrm{C}$ in the summer (Ávila et al., 2008c). The gonadosomatic

421 index of S. cretense (which is closely associated with mean temperature) increases in

422 the Azores from June to August and then drops to a minimum in November (Afonso et

423 al., 2008). Hence, although it mainly breeds from mid-July to mid-September, it is

424 possible that this species extends its reproductive activity through October (Afonso et

425 al., 2008). Therefore, in our opinion, neither temperature nor habitat shift were an

426 impediment for the survival of this species in the Azores throughout the last glacial

427 episode. Our view differs from that of previous authors, who suggested that the drop

428 of sea temperatures (...) that occurred during the Pleistocene probably resulted in

429 mass extinctions' (of fishes) and so 'most of the organisms now present would have

430 reached the Azores in the last 17,000 years' (Santos et al., 1995). Our reasoning also

431 contradicts the conclusions of Domingues et al. (2008), who stated that 'persistence of 
432 (...) S. cretense in the Azores archipelago during the Pleistocene glaciations is difficult

433 to admit'. Moreover, the very abundant and well-studied MIS 5e (i.e. Last Interglacial)

434 fossil record from Santa Maria Island disproves the conclusions of these former 435 authors.

436 The finding of fossil pharyngeal plates belonging to $S$. cretense in MIS 5e

437 sediments does not necessarily exclude the hypothesis that this species locally

438 disappeared during the Last Glaciation, only to recolonize the archipelago post-

439 glacially. Nevertheless, we consider it more plausible to argue that such extirpation did

440 not happen, taking in consideration the following: (1) detailed studies on the Azorean

441 MIS 5e and recent marine molluscs showed that the drop of the SSTs during the Last

442 Glaciation only affected two groups of species: the tropical species that reached the

443 Azores probably during a 'window of opportunity' associated with the final phase of

444 Termination 2, and bivalve species associated to fine-sand sediments; both groups

445 were extirpated (Ávila et al., 2008a, 2008b, 2009b, 2015a); (2) as temperature is

446 known to play a key role on marine fish species biology (Pepin, 1991; van der Kraak \&

447 Pankhurst, 1997; Pankhurst \& Porter, 2003; Dolomatova et al., 2013; Poloczanska et

448 al., 2016) and in light of the premises pointed above, the drop of SSTs was not

449 sufficient enough to severely affect the survival, growth and reproduction of the

450 temperate parrotfish S. cretense in the Azores during the Last Glacial episode; (3)

451 finally, if S. cretense was a post-glacial colonizer of the Azores, the genetic diversity of

452 the Azorean populations should be low, in comparison with southern Madeiran

453 populations (postulated to have not been affected by the drop of SSTs), but that is not

454 the case, as pointed out by Domingues et al. (2008). Thus, combining our

455 palaeontological data with ecological and genetic data from other authors (Abecasis et 

al., 2008; Afonso et al., 2008; Domingues et al., 2008), we believe the most plausible scenario is the survival of most (if not all) temperate and subtropical fish species in the Azores during the Last Glacial episode, so long as their ecological traits are not tied on sandy habitats. This contribution expands the number of Pliocene fishes reported from the

461 Azores to at least 11 taxa: seven taxa of Chondrichthyes (Ávila et al., 2012): Carcharias 462 acutissima (Agassiz, 1833), Carcharhinus cf. leucas (Valenciennes, 1839 in Müller and 463 Henle, 1839-1841), Cosmopolitodus hastalis (Agassiz, 1833), Isurus oxyrinchus 464 Rafinesque, 1810, Otodus (Megaselachus) megalodon (Agassiz in Charlesworth, 1837), 465 Notorynchus primigenius (Agassiz, 1833) and Paratodus benedenii (Le Hon, 1871); and 466 four of Actinopterygii (this work): at least two Sparidae indet. taxa, Labrodon

467 pavimentatum and Sparisoma cretense. Most of these are also reported for the 468 Pliocene of Canaries (Betancort et al., 2016), the exceptions being Carcharhinus cf. 469 priscus (Agassiz, 1843), Diodon scillae Agassiz, 1843 and Galeocerdo cf. aduncus 470 Agassiz, 1843, only reported for Canary Islands; and Sparidae indet., N. primigenius 471 and S. cretense, only reported for the Azores. The high number of shared species on 472 archipelagos over $1,100 \mathrm{~km}$ apart is understandable if it is taken into consideration 473 that during the Pliocene both archipelagos were part of the same Atlantic

474 biostratigraphic molluscan province [the Pliocene Mediterranean-West African 475 Province of Ávila et al. (2016); see Fig.8B] sharing similar tropical palaeoclimatic 476 conditions.

\section{Conclusions}


480 the fossil record. The discovery of several pharyngeal plates of S. cretense on Pliocene 481 and on MIS 5e sediments (Last Interglacial) of Santa Maria Island challenges former 482 authors (Briggs, 1974; Santos et al., 1995; Domingues et al., 2006, 2008) who argued

483 that mass extinctions affected the shallow-water marine fauna of the Azores during 484 the course of the Last Glaciation and that, as a consequence, most of the present 485 Azorean marine species colonized the area during the last 17-18 kyr. A

486 multidisciplinary approach, merging our palaeontological data with ecological and 487 genetic data, offers an alternative, more plausible explanation, suggesting that most (if 488 not all) of the Azorean shallow-water subtropical and temperate marine species living 489 in the archipelago during the Last Interglacial (and probably in previous interglacials as 490 well) and associated to non-mobile sediments (e.g., rocky shores, covered or not by 491 algae), were not affected by the drop of the SSTs during the Last Glacial episode. Finally, we also predict that the only marine fish species that were extirpated

493 from the Azores during the course of the Last Glaciation were those associated with

494 fine sand (Fig. 8G-I), and the thermophilic species that colonized the archipelago 495 during the Last Interglacial/Termination 2 'window of opportunity' (Fig. 8D-F).

496 Whether fish species ecologically associated with fine sediments and presently living in 497 the Azores are post-glacial colonizers or 'bottleneck' survivors from the Last Glaciation 498 should be assessed by genetic tools, as we anticipate low genetic diversity of the 499 Azorean populations, when compared with continental counterparts. 
502 We thank Direcção Regional da Ciência e Tecnologia (Regional Government of the

503 Azores), FCT (Fundação para a Ciência e a Tecnologia) of the Portuguese Government,

504 and Câmara Municipal de Vila do Porto for financial support, and acknowledge the

505 field assistance of Clube Naval de Santa Maria and Câmara Municipal de Vila do Porto.

506 We are grateful to the organizers and participants of all editions of the International

507 Workshop Palaeontology in Atlantic Islands who helped with fieldwork (2002-2017).

508 We thank F. Couto (Hobby Factor) for the aerial/drone photos. We thank M. Ramalho

509 and J. Anacleto (Museu Geológico, LNEG, Lisbon), for allowing access to their historical

510 collections. SPA acknowledges his research contract (IF/00465/2015) funded by the

511 Portuguese Science Foundation (FCT). LB acknowledges her PhD Grant from FCT

512 (SFRH/BD/135918/2018). CSM is benefiting from a PhD grant M3.1.a/F/100/2015 from

513 Fundo Regional para a Ciência e Tecnologia (FRCT). This research also received

514 substantial support from the SYNTHESYS Project (http://www.synthesys.info/), which

515 is financed by the European Community Research Infrastructure Action under the FP7

516 'Capacities' Program: SPA studied fossil collection at the Museum für Naturkunde,

517 Berlin (DE-TAF-1071). This work also was supported by FEDER funds through the

518 Operational Programme for Competitiveness Factors - COMPETE, and by National

519 Funds through FCT under the UID/BIA/50027/2013, POCI-01-0145-FEDER-006821 and

520 under DRCT-M1.1.a/005/Funcionamento-C-/2016 (CIBIO-A) project from FRCT. This

521 work was also supported by FEDER funds (in 85\%) and by funds of the Regional

522 Government of the Azores (15\%) trough Programa Operacional Açores 2020, in the

523 scope of the project "AZORESBIOPORTAL - PORBIOTA": ACORES-01-0145-FEDER-

524000072. 


\section{Author Contributions}

528 S.P.A and R.V. designed the research plan. S.P.A., P.M., R.C. and R.V. collected the 529 fossil material. C.S.M. constructed all figures. S.P.A., M.E.J and R.V. wrote the

530 manuscript, with input from all authors, who discussed and commented on the

531 manuscript.

532

533

534 Additional Information

535 Competing Interests: The authors declare no competing interests.

536

537

538

References

539

Abecasis, D., Bentes, L., Ribeiro, J., Machado, D., Oliveira, F., Veiga, P., Gonçalves, J. M. S. \& Erzini, K., 2008. First record of the Mediterranean parrotfish, Sparisoma cretense in Ria Formosa (south Portugal). Marine Biodiversity Records 1, e27.

542 Afonso, P., Morato, T. \& Santos, R. S., 2008. Spatial patterns in reproductive traits of the temperate parrotfish Sparisoma cretense. Fisheries Research 90, 92-99.

544 Antunes, M.T., Jonet, S. \& Nascimento, A., 1981: Vertébrés (crocodiliens, poissons) du Miocène marin de l'Algarve occidentale. Ciências da Terra, 6: 9-38.

546 Arambourg, C., 1927: Les poissons fossiles d'Oran. Matériaux pour la carte géologique de l’Algérie, Paléontologie, Alger, 6: 1-293. 
548 Ávila, S. P., 2000. Shallow-water marine molluscs of the Azores: biogeographical relationships. Arquipélago Life and Marine Sciences. Supplement 2(Part A), 99-131.

551

Ávila, S. P., 2013. Unravelling the patterns and processes of evolution of marine life in oceanic islands: a global framework; pp. : 95-125 in: J. M. Fernández-Palacios, L. de Nascimento, J. C. Hernández, S. Clemente, A. González, and J. P. DíazGonzález (Eds.), Climate Change perspectives from the Atlantic: past, present and future. Universidad de La Laguna, Tenerife.

Ávila, S. P., Amen, R., Azevedo, J. M. N., Cachão, M. \& García-Talavera, F., 2002. Checklist of the Pleistocene marine molluscs of Prainha and Lagoinhas (Santa Maria Island, Azores). Açoreana 9, 343-370.

Ávila, S. P., Madeira, P., Mendes, N., Rebelo, A. C., Medeiros, A., Gomes, C., GarcíaTalavera, F., da Silva, C. M., Cachão, M., Hillaire-Marcel, C. \& Martins, A. M. F., 2008a. Mass extinctions in the Azores during the last glaciation: fact or myth? Journal of Biogeography 35, 1123-1129.

Ávila, S. P., da Silva, C. M., Cachão, M., Landau, B., Quartau, R. \& Martins, A. M. F., 2008b. Local disappearance of bivalves in the Azores during the last glaciation. Journal of Quaternary Science 23, 777-785.

Ávila, S. P., Melo, P. J., Lima, A., Amaral, A., Martins, A. M.F. \& Rodrigues, A., 2008c. The reproductive cycle of the rissoid Alvania mediolittoralis Gofas, 1989 (Mollusca, Gastropoda) at São Miguel Island (Azores, Portugal). Journal of Invertebrate Reproduction and Development 52, 31-40.

Ávila, S. P., da Silva, C. M., Schiebel, R., Cecca, F., Backeljau, T. \& Martins, A. M. F., 2009a. How did they get here? Palaeobiogeography of the Pleistocene marine 
molluscs of the Azores. Bulletin of the Geological Society of France 180, 295307.

Ávila, S. P., Madeira, P., Zazo, C., Kroh, A., Kirby, M., da Silva, C. M., Cachão, M. \& Martins, A. M. F., 2009b. Palaeoecology of the Pleistocene (MIS 5.5) outcrops of Santa Maria Island (Azores) in a complex oceanic tectonic setting. Palaeogeography, Palaeoclimatology, Palaeoecology 274, 18-31.

Ávila, S. P., Rebelo, A. C., Medeiros, A., Melo, C., Gomes, C., Bagaço, L., Madeira, P., Borges, P. A., Monteiro, P., Cordeiro, R., Meireles, R. \& Ramalho, R. S., 2010. Os fósseis de Santa Maria (Açores). 1. A jazida da Prainha, 103 pp. OVGA Observatório Vulcanológico e Geotérmico dos Açores, Lagoa (2010).

Ávila, S. P., Ramalho, R. S. \& Vullo, R., 2012. Systematics, palaeoecology and palaeobiogeography of the Neogene fossil sharks from the Azores (Northeast Atlantic). Annales de Paléontologie 98, 167-189.

Ávila, S. P., Melo, C., Silva, L., Ramalho, R. S., Quartau, R., Hipólito, A., Cordeiro, R., 586

Ávila, S. P., Ramalho, R. S., Habermann, J. M., Quartau, R., Kroh, A., Berning, B., Rebelo, A. C., Madeira, P., Rovere, A., Hearty, P. J., Henriques, D., da Silva, C. M., Martins, A. M. F. \& Zazo, C., 2015a. A review of the MIS 5e highstand deposits from Santa Maria Island (Azores, NE Atlantic): palaeobiodiversity, palaeoecology and palaeobiogeography. Quaternary Science Reviews 114, $126-148$. Johnson, M. E., Kirby, M. X., Zanon, V., Titschack, J., Goss, A., Rebelo, A. C., Melo, C., Madeira, P., Cordeiro, R., Meireles, R., Bagaço, L., Hipólito, A., Uchman, A., da Silva, C. M., Cachão, M. \& Madeira, J., 2015b. Palaeoecology, taphonomy, and preservation of a lower Pliocene shell bed (coquina) from a 
volcanic oceanic island (Santa Maria Island, Azores, NE Atlantic Ocean). Palaeogeography, Palaeoclimatology, Palaeoecology 430, 57-73.

Ávila, S. P., Cordeiro, R., Rodrigues, A. R., Rebelo, A. C., Melo, C., Madeira, P. \& Pyenson, N. D., 2015c. Fossil Mysticeti from the Pleistocene of Santa Maria Island, Azores (NE Atlantic Ocean), and the prevalence of fossil cetaceans on oceanic islands. Palaeontologia Electronica 18.2.27A, 1-12.

Ávila, S. P., Melo, C., Berning, B., Cordeiro, R., Landau, B. \& da Silva, C. M., 2016. Persististrombus coronatus (Mollusca: Strombidae) in the early Pliocene of Santa Maria Island (Azores: NE Atlantic): palaeoecology, palaeoclimatology and palaeobiogeographic implications on the NE Atlantic Molluscan Biogeographical Provinces. Palaeogeography, Palaeoclimatology, Palaeoecology 441, 912-923.

Ávila, S. P., Ramalho, R. S., Habermann, J. M. \& Titschack, J., 2018. The marine fossil

Ávila, S. P., Melo, C., Sá, N., Quartau, R., Rijsdijk, K., Ramalho, R. S., Berning, B., Cordeiro, R., de Sá, N. C., Pimentel, A., Baptista, L., Medeiros, A., Gil, A. \& Johnson, M. E., 2019. Towards a "Sea-Level Sensitive Marine Island Biogeography" model: the impact of glacio-eustatic oscillations in global marine island biogeographic patterns. Biological Reviews 94, 1116-1142. M. \& Cachão, M., 2013. What Darwin did not see: Pleistocene fossil 
Baarli, B. G., Malay, M. C. D., Santos, A., Johnson, M. E., da Silva, C. M., Meco, J., Cachão, M. \& Mayoral, E. J., 2017. Miocene to Pleistocene transatlantic dispersal of Ceratoconcha coral-dwelling barnacles and North Atlantic island biogeography. Palaeogeography, Palaeoclimatology, Palaeoecology 468, 520528.

Bauzá, J., 1948. Nuevas aportaciones al conocimiento de la ictiología del Neógeno catalano-balear. Estudios Geológicos, 8: 221-239.

Bauzá, J. \& Plans, J., 1973. Contribución al conocimiento de la fauna ictiológica del Neógeno Catalano Balear. Boletín de la Sociedad de Historia Natural de las Baleares, 28: 72-131.

Bellwood, D. R. \& Schultz, O., 1991. A Review of the fossil record of the parrotfishes (Labroidei: Scaridae) with a description of a new Calotomus species from the middle Miocene (Badenian) of Austria. Annalen des Naturhistorischen Museums in Wien 92, 55-71.

Bellwood, D. R., Schultz, O., Siqueira, A. C. \& Cowman, P. F., 2019. A review of the fossil record of the Labridae. Annalen des Naturhistorischen Museums in Wien, Serie A 121, 125-193.

Bernardi, G., Robertson, D. R., Clifton, K. E. \& Azzurro, E., 2000. Molecular systematics, zoogeography, and evolutionary ecology of the Atlantic parrotfish genus Sparisoma. Molecular Phylogenetics and Evolution 15, 292-300. 
641 Betancort, J. F., Lomoschitz, A. \& Meco, J., 2014. Mio-Pliocene crustaceans from the Carany Islands, Spain. Rivista Italiana di Paleontologia e Stratigrafia 120, 337349.

Betancort, J. F., Lomoschitz, A. \& Meco, J., 2016. Early Pliocene fishes (Chondrichthyes, Osteichthyes) from Gran Canaria and Fuerteventura (Canary Islands, Spain). Estudios Geológicos 72, e054.

Beu, A. G., 2017. Evolution of Janthina and Recluzia (Mollusca: Gastropoda: Epitoniidae). Records of the Australian Museum 69, 119-222.

Blanc, P.-L., 2002. The opening of the Plio-Quaternary Gibraltar Strait: assessing the size of a cataclysm. Geodinamica Acta 15, 303-317.

Briggs, J. C., 1974. Marine zoogeography. McGraw-Hill, New York, 475 pp.

Briggs, J. C., 1995. Global Biogeography. Elsevier, Amsterdam, 452 pp.

Bullock, A. E. \& Monod, T., 1997. Myologie céphalique de deux poissons perroquets (Teleostei: Scaridae). Cybium 21, 173-199.

Cocchi, I., 1864. Monografia dei Pharyngodopilidae. Nuova famiglia di Pesci Labroidi. Annali del Museo Imperiale di Fisica e Storia Naturale di Firenze 1, 62-152.

Cordeiro, R., Borges, J. P., Martins, A. M. F. \& Ávila, S. P., 2015. Checklist of the littoral gastropods (Mollusca: Gastropoda) from the Archipelago of the Azores (NE Atlantic). Biodiversity Journal 6, 855-900.

Crowley, T. J., 1981. Temperature and circulation changes in the eastern North Atlantic during the last 150,000 years: Evidence from the planktonic foraminiferal record. Marine Micropaleontology 6, 97-129.

663 Cutwa, M. M., \& Turingan, R. G., 2000. Intralocality variation in feeding biomechanics 664 and prey use in Archosargus probatocephalus (Teleostei, Sparidae), with 

59, 191-198.

Darwin, C., 1859. On the origin of species by means of natural selection, or the 668 preservation of favoured races in the struggle for life. John Murray, London, $502 \mathrm{pp}$.

Day, J. J., 2002. Phylogenetic relationships of the Sparidae (Teleostei: Percoidei) and implications for convergent trophic evolution. Biological Journal of the Linnean Society 76, 269-301.

Dolomatova, S., Zukowb, W. \& Brudnickib, R., 2013. Role of temperature in regulation

675 of the life cycle of temperate fish. Russian Journal of Marine Biology 39, 8191.

Domingues, V. S., Santos, R. S., Brito, A. \& Almada, V. C., 2006. Historical population dynamics and demography of the eastern Atlantic pomacentrid Chromis limbata (Valenciennes, 1833). Molecular Phylogenetics and Evolution 40, 139147.

Domingues, V. S., Alexandrou, M., Almada, V. C., Robertson, D. R., Brito, A., Santos, R. S. \& Bernardi, G., 2008. Tropical fishes in a temperate sea: evolution of the wrasse Thalassoma pavo and the parrotfish Sparisoma cretense in the Mediterranean and the adjacent Macaronesian and Cape Verde Archipelagos. Marine Biology 154, 465-474.

Estevens, M. \& Ávila, S. P., 2007. Fossil whales from the Azores. Açoreana Suplemento 5, 140-161.

Fernández-Palacios, J.M., Rijsdijk, K. F., Norder, S. J., Otto, R., de Nascimento, L., Fernández-Lugo, S., Tjørve, E. \& Whittaker, R. J., 2016. Towards a glacial- 

$817-830$.

Ferreira, O. da V., 1955. A fauna miocénica da ilha de Santa Maria (Açores). Comunicações dos Serviços Geológicos de Portugal 36, 9-44.

Froese, R. \& Pauly, D. (eds), 2018. FishBase. Sparisoma cretense. Available from http://www.fishbase.org, version (06/2018). Accessed on 4 October 2018.

Gagnaison, C., 2017. Le site paléontologique du Grand Morier (Pont-Boutard, Indre-etLoire, France): contexte géologique et détail biostratigraphique des formations cénozoïques à partir des assemblages de vertébrés fossiles. Geodiversitas 39, $251-271$.

Garcia-Castellanos, D., Estrada, F., Jiménez-Munt, I., Gorini, C., Fernàndez, M., Vergés, J. \& de Vicente, R., 2009. Catastrophic flood of the Mediterranean after the Messinian salinity crisis. Nature $\mathbf{4 6 2}, \mathbf{7 7 8}-781$.

Guidetti, P. \& Boero, F., 2002. Spatio-temporal variability in abundance of the parrotfish, Sparisoma cretense, in SE Apulia (SE Italy, Mediterranean Sea). Italian Journal of Zoology 69, 229-232.

Harzhauser, M., Piller, W. E. \& Steininger, F. F., 2002. Circum-Mediterranean OligoMiocene biogeographic evolution - the gastropods' point of view. Palaeogeography, Palaeoclimatology, Palaeoecology 183, 103-133. (Mollusca, Gastropoda) from Santa Maria (Azores, Portugal): systematics and biostratigraphic implications. Acta Geologica Polonica 58, 355-369.

711 Johnson, M. E., Ramalho, R. S., Baarli, B. G., Cachão, M., da Silva, C. M., Mayoral, E. J. \& Santos, A., 2014. Miocene-Pliocene rocky shores on São Nicolau (Cape Verde 

Islands): Contrasting windward and leeward biofacies on a volcanically active oceanic island. Palaeogeography, Palaeoclimatology, Palaeoecology 395, 131143.

Johnson, M. E., Uchman, A., Costa, P. J. M., Ramalho, R. S. \& Ávila, S.P., 2017. Intense hurricane transport sand onshore: example from the Pliocene Malbusca section on Santa Maria Island (Azores, Portugal). Marine Geology 385, 244249.

Jonet, S., 1968. Notes d'ichthyologie miocène portugaise. IV - Les Labridae. Boletim da Sociedade Geológica de Portugal 16, 209-221.

Jonet, S., 1975. Notes d'ichthyologie Miocene Portugaise. Boletim da Sociedade Geológica de Portugal, 29(3): 135-173.

Jonet, S., Kotchetoff, Y. \& Kotchetoff, B., 1975. L'helvétien du Penedo et sa faune ichthyologique. Comunicações dos Serviços Geológicos de Portugal 59, 193228.

van der Kraak, G. \& Pankhurst, N. W., 1997. Temperature effects on the reproductive performance of fish; pp. 159-176 in Wood, C. M. \& Macdonald D. G. (Eds.), Global warming: implications for freshwater and marine fish. CUP, Cambridge.

Kroh, A., Bitner, M. A. \& Ávila, S. P., 2008. Novocrania turbinata (Brachiopoda) from the Early Pliocene of the Azores (Portugal). Acta Geologica Polonica 58, 473478.

Laughton, A. S., \& Whitmarsh, R. B., 1974. The Azores-Gibraltar plate boundary; pp. 63-81 in L. Kristjansson (Ed.), Geodynamics of Iceland and the North Atlantic Area. Kufstein, Austria. 
736 Laurito, C. A., Calvo, C., Valerio, A. L., Calvo, A. \& Chacón, R., 2014. Ictiofauna del mioceno inferior de la localidad de Pacuare de Tres Equis, formación río Banano, provincia de Cartago, Costa Rica, y descripción de un nuevo género y una nueva especie de Scaridae. Revista Geológica de América Central 50, 153192.

Lecointre, G., 1952. Recherches sur le Néogène et le Quaternaire marin de la Côte Atlantique du Maroc, Tome 2 - Paléontologie. Notes et Mémoires du Service

Lisiecki, L. E. \& Raymo, M. E., 2005. A Pliocene-Pleistocene stack of 57 globally distributed benthic $\delta 180$ A Pliocene-Pleistocene stack of 57 globally distributed benthic $\delta^{18} \mathrm{O}$ records. Paleoceanography 20, PA1003.

de Lumley, H., 1988. La stratigraphie du remplissage de la Grotte du Vallonnet. L'Anthropologie 92, 407-428.

Madeira, P., Kroh, A., Martins, A. M. F. \& Ávila, S. P., 2007. The marine fossils from Santa Maria Island (Azores, Portugal): an historical overview. Açoreana Suplemento 5, 59-73.

Madeira, P., Kroh, A., Cordeiro, R., Meireles, R. \& Ávila, S. P., 2011. The fossil echinoids of Santa Maria Island, Azores (Northern Atlantic Ocean). Acta Geologica Polonica 61, 243-264.

Martín-González, E., Buckeridge, J., Castillo, C. \& García-Talavera, F., 2012. First record of a tropical shallow water barnacle Tetraclita sp. (Cirripedia: Tetraclitoidea)

Mas, G. \& Antunes, M. T., 2008. Presència de Tomistoma cf. lusitanica (Vianna i Moraes, 1945) (Reptilia: Crocodylia) al Burdigalià inferior de Mallorca (Illes Balears, 
Mediterrània occidental). Implicacions paleoambientals. Bolletí de la Societat d'Història Natural de les Balears 51, 131-146.

Meco, J., 1977. Los Strombus Neogenos y Cuaternarios del Atlantico Eurafricano. (Taxonomia, Biostratigrafia y Palaeoecologia). Palaeontologia de Canarias 1, $1-142$.

Meco, J., Petit-Maire, N., Fontugne, M., Shimmield, G. \& Ramos, A. J., 1997. The Quaternary deposits in Lanzarote and Fuerteventura (Eastern Canary Islands, Spain): an overview; pp. 123-136 in J. Meco, and N. Petit-Maire (Eds.), Climates of the Past-Proceedings of the CLIP meeting 1995. Universidad de Las Palmas de Gran Canaria, Servicio de Publicaciones, Gran Canaria.

Meco, J., Scaillet, S., Guillou, H., Lomoschitz, A., Carracedo, J. C., Ballester, J., Betancort, J.-F. \& Cilleros, A., 2007. Evidence for long-term uplift on the Canary Islands from emergent Mio-Pliocene littoral deposits. Global and

Meco, J., Koppers, A. A. P., Miggins, D. P., Lomoschitz, A. \& Betancort, J.-F., 2015. The Canary record of the evolution of the North Atlantic Pliocene: New ${ }^{40} \mathrm{Ar} /{ }^{39} \mathrm{Ar}$ ages and some notable palaeontological evidence. Palaeogeography, Palaeoclimatology, Palaeoecology 435, 53-69.

Meco, J., Lomoschitz, A. \& Betancort, J.-F., 2016. Early Pliocene tracer of North Atlantic 197. Miocene marine ostracods from Santa Maria Island, Azores (NE Atlantic): 
Systematics, palaeoecology and palaeobiogeography. Revue de Micropaléontologie 55, 133-148.

Meireles, R. P., Keyser, D. \& Ávila, S. P., 2014. The Holocene to Recent ostracods of the Azores (NE Atlantic): systematics and biogeography. Marine Micropaleontology 112, 13-26.

Nolf, D., 1988. Les otolithes de téléosténs éocènes d'Aquitaine (sud-ouest de la France) et leur intérêt stratigraphique. Académie Royale de Belgique, Mémoires de la Classe des Sciences, Collection 4, (Serie 2) 19, 1-147. Bruxelles.

Obrador, A. \& Mercadal, B., 1973. Nuevas localidades con fauna ictiológica para el Neógeno menorquín. Acta Geológica Hispánica 8, 115-119.

O’Dea, A., Lessios, H. A., Coates, A. G., Eytan, R. I., Restrepo-Moreno, S. A., Cione, A. L., Collins, L. S., de Queiroz, A., Farris, D. W., Norris, R. D., Stallard, R. F., Woodburne, M. O., Aguilera, O., Aubry, M.-P., Berggren, W. A., Budd, A. F., Cozzuol, M. A., Coppard, S. E., Duque-Caro, H., Finnegan, S., Gasparini, G. M., Grossman, E. L., Johnson, K. G., Keigwin, L. D., Knowlton, N., Leigh, E. G., Leonard-Pingel, J. S., Marko, P. B., Pyenson, N. D., Rachello-Dolmen, P. G., Soibelzon, E., Soibelzon, L., Todd, J. A., Vermeij, G. J. \& Jackson, J. B. C., 2016. Formation of the Isthmus of Panama. Science Advances 2, e1600883.

Pankhurst, N. W. \& Porter, M. J. R., 2003. Cold and dark or warm and light: variations on the theme of environmental control of reproduction. Fish Physiology and Biochemistry 28, 385-389. rates of the pelagic early life history stages of marine fish. Canadian Journal of Fisheries and Aquatic Sciences 48, 503-518. 
Poloczanska, E. S., Burrows, M. T., Brown, C. J., García Molinos, J., Halpern, B. S., Hoegh-Guldberg, O., Kappel, C. V., Moore, P. J., Richardson, A. J., Schoeman, D. S. \& Sydeman, W. J., 2016. Responses of Marine Organisms to Climate Change across Oceans. Frontiers Marine Science 3, 62 (2016).

812 Quignard, J.-P. \& Pras, A., 1986. Scaridae; Vol. II, pp. 943-944 in Whitehead, P. J. P., Bauchot, M.-L., Hureau, J.-C., Nielsen, J. \& Tortonese, E. (Eds), Fishes of the North-eastern Atlantic and the Mediterranean. UNESCO, Paris.

Ramalho, R. S., Helffrich, G., Madeira, J., Cosca, M., Thomas, C., Quartau, R., Hipólito, A., Rovere, A., Hearty, P. J. \& Ávila, S. P., 2017. The emergence and evolution of Santa Maria Island (Azores) - the conundrum of uplifted islands revisited.

Randall, J. E., 1990. Scaridae; Vol. II, pp. 883-887 in J. C. Quero, J. C. Hureau, C. Karrer, A. Post, and L. Saldanha (Eds.), Check-list of the fishes of the eastern tropical Atlantic. JNICT, Lisbon; SEI, Paris; and UNESCO, Paris.

Raposo, V. B., Melo, C. S., Silva, L., Ventura, A., Câmara, R., Pombo, J., Johnson, M. E. \& Ávila, S. P., 2018. Comparing methods of evaluation of geosites: the fossiliferous outcrops of Santa Maria Island (Azores, NE Atlantic) as a case study for sustainable island tourism. Sustainability 10, 3596.

Rebelo, A. C., Rasser, M. W., Riosmena-Rodríguez, R., Neto, A. I. \& Ávila, S. P., 2014. Rhodolith forming coralline algae in the Upper Miocene of Santa Maria Island (Azores, NE Atlantic): a critical evaluation. Phytotaxa 190, 370-382. 

121.

Rebelo, A. C., Rasser, M. W., Kroh, A., Johnson, M. E., Ramalho, R. S., Melo, C., Uchman, A., Berning, B., Silva, L., Zannon, V., Neto, A. I., Cachão, M. \& Ávila, S. P., 2016b. Rocking around a volcanic island shelf: Pliocene Rhodolith beds from Malbusca, Santa Maria Island (Azores, NE Atlantic). Facies 62, 22.

Ricchi, A., Quartau, R., Ramalho, R. S., Romagnoli, C., Casalbore, D., da Cruz, J. V., Fradique, C. \& Vinhas, A., 2018. Marine terrace development on reefless volcanic islands: New insights from high-resolution marine geophysical data offshore Santa Maria Island (Azores Archipelago). Marine Geology 406, 42-56.

Sacco, F., 1916. Apparati dentali di Labrodon e di Chrysophrys del Pliocene italiano. Memorie della Reale Accademia delle Scienze di Torino 60, 144-149.

Santos, A., Mayoral, E. J., da Silva, C. M., Cachão, M. \& Johnson, M. E., 2011. Miocene intertidal zonation on a volcanically active shoreline: Porto Santo in the Madeira Archipelago, Portugal. Lethaia 44, 26-32.

Santos, A., Mayoral, E., Baarli, B. G., da Silva, C. M., Cachão, M. \& Johnson, M. E., 2012a. Symbiotic association of a Pyrgomatid barnacle with a coral from the volcanic Middle Miocene shoreline (Porto Santo, Madeira archipelago, Portugal). Palaeontology 55, 173-182. Ledesma-Vázques, J., 2012b. Extreme habitat adaptation by boring bivalves on volcanically active paleoshores from North Atlantic Macaronesia. Facies 58, 325-338. 
854 Santos, A., Mayoral, E., Dumont, C. P., da Silva, C. M., Ávila, S. P., Baarli, B. G., Cachão,

855

856

857

858

859

860

861

862

863

864

865

866

867

868

869

870

871

872

873

874

875

876

877

M., Johnson, M. E. \& Ramalho, R. S., 2015. Role of environmental change in rock-boring echinoid trace fossils. Palaeogeography, Palaeoclimatology, Palaeoecology 432, 1-14.

Santos, R. S., Hawkins, S., Monteiro, L. R., Alves, M. \& Isidro, E. J., 1995. Marine research, resources and conservation in the Azores. Aquatic Conservation: Marine and Freshwater Ecosystems 5, 311-354.

Sauvage, H.-E., 1875. Note sur le genre Nummopalatus et sur les espèces de ce genre trouvés dans les terrains tertiaires de la France. Bulletin de la Société Géologique de France 3, 613-642.

Searle, R., 1980. Tectonic pattern of the Azores spreading centre and triple junction. Earth and Planetary Science Letters 51, 415-434.

Simonelli, V., 1889. Terreni e fossili dell'Isola di Pianosa nel Mar Tirreno. Bolletino del Reale Comitato Geolologico d'Italia 10, 193-237.

Tuya, F., Betancort, J. F., Haroun, R., Espino, F., Lomoschitz, A. \& Meco, J., 2017. Seagrass paleo-biogeography: Fossil records reveal the presence of Halodule cf. in the Canary Islands (eastern Atlantic). Aquatic Botany 143, 1-7.

Uchman, A., Johnson, M. E., Rebelo, A. C., Melo, C., Cordeiro, R., Ramalho, R. S. \& Ávila, S. P., 2016. Vertically-oriented trace fossil Macaronichnus segregatis from Neogene of Santa Maria Island (Azores; NE Atlantic) records vertical fluctuations of the coastal groundwater mixing zone on a small oceanic island. Geobios 49, 229-241.

Uchman, A., Quintino, V., Rodrigues, A. M., Johnson, M. E., Melo, C., Cordeiro, R., Ramalho, R. S. \& Ávila, S. P., 2017. The trace fossil Diopatrichnus 

santamariaensis nov. isp. - a shell armoured tube from Pliocene sediments of Santa Maria Island, Azores (NE Atlantic Ocean). Geobios 50, 459-469.

880 Vicens, D. \& Rodríguez-Perea, A., 2003. Vertebrats fòssils (Pisces i Reptilia) del Burdigalià 881 de cala Sant Vicenç (Pollença, Mallorca). Bolletí de la Societat d'Història Natural de les Balears 46, 117-130.

Vogt, P. R., \& Jung, W.-Y., 2018. The "Azores Geosyndrome" and Plate Tectonics: Research History, Synthesis, and Unsolved Puzzles; pp. 27-56 in U. Kueppers, and C. Beier (Eds.), Volcanoes of the Azores. Revealing the Geological Secrets of the Central Northern Atlantic Islands. Springer, Berlin.

Wallace, A. R., 1880. Island life, or, the phenomena and causes of insular faunas and floras: including a revision and attempted solution of the problem of geological climates. Macmillan, London, 526 pp.

Whittaker, R. J., Triantis, K. A. \& Ladle, R. J., 2010. A General Dynamic Theory of Oceanic Island Biogeography: Extending the MacArthur-Wilson Theory to Accommodate the Rise and Fall of Volcanic Islands; pp. 88-115 in J. B. Losos, and R. E. Ricklefs (Eds.), The theory of island biogeography revisited. Princeton University Press, Princeton, New Jersey.

Winkelmann, K., Buckeridge, J. S., Costa, A. C., Dionísio, M. A. M., Medeiros, A., Cachão, M. \& Ávila, S. P., 2010. Zullobalanus santamariaensis sp. nov., a new late Miocene barnacle species of the family Archeobalanidae (Cirripedia: Thoracica), from the Azores. Zootaxa 2680, 33-44. http://www.marinespecies.org at VLIZ. Accessed on 4 October 2018. 
901 Zbyszewski, G. \& Moitinho d'Almeida, F., 1950. Os peixes miocénicos portugueses.

902 Comunicações dos Serviços Geológicos de Portugal 31, 309-423.

903 Zbyszewski, G. \& da V. Ferreira, O., 1962. La faune miocène de l'île de Santa Maria

904 (Açores). Comunicações dos Serviços Geológicos de Portugal 46, 247-289.

905

906 
908 Figure 1. A: Location of the Azores Archipelago in the NE Atlantic, and location and

909 geotectonic setting of Santa Maria Island within the Azores Archipelago and within the

910 Azores triple junction, respectively. The light blue area represents the Azores plateau

911 (see text). MAR: Mid-Atlantic Ridge; EAFZ: East Azores fault zone; GF: Gloria fault; NA:

912 North American plate; Eu: Eurasian plate; Nu: Nubian (African) plate. B: location of the

913 Pliocene (red circles) and Pleistocene fossiliferous outcrops (yellow triangles) of Santa

914 Maria Island. The Pleistocene outcrops are restricted to the warmest interval of the

915 Last Interglacial Period (c. 116-130 kyr), which is known as MIS 5e (Marine Isotopic

916 Substage 5e). [Intended for page width].

917

918 Figure 2. Aerial (drone) views of the fossiliferous outcrops from Santa Maria Island. A-

919 B: Pliocene outcrops; C-D: Pleistocene (MIS 5e) outcrops. The white line delimits the

920 outcrops. A: Cré. B: Figueiral. C: Prainha (the white arrows point to the areas where

921 fossiliferous sediments are better preserved). D: Vinha Velha. [Intended for page

922 width].

923

924 Figure 3. Aerial (drone) views of the Pliocene fossiliferous outcrops from Santa Maria

925 Island. The white line delimits the outcrops. A: Malbusca. B: West fault of Malbusca. C:

926 Pedra-que-pica. At West fault of Malbusca (B), the fossil strata are displaced by a fault

927 slip of about $20 \mathrm{~m}$. Pedra-que-pica (C) is probably the largest worldwide multispecific

928 coquina ever described from a volcanic oceanic island, with a total estimated area of

$929>23,400 \mathrm{~m}^{2}$ and a total thickness for the sediments of 10-11 m (Ávila et al., 2015b).

$930 \quad$ [Intended for page width]. 
932 Figure 4. Stratigraphic columns of the studied outcrops: Malbusca (Rebelo et al., 933 2016a; Uchman et al., 2017), Figueiral (Ávila et al., 2018), Pedra-que-pica (Ávila et al.,

934 2015b), West fault of Malbusca (Uchman et al., 2017), Cré (Janssen et al., 2008),

935 Prainha and Vinha Velha (Ávila et al., 2010, 2015a). [Intended for page width].

936

937 Figure 5. Actinopterygian fishes from Early Pliocene deposits of Santa Maria Island

938 (Azores). A-L: Teeth of Sparidae indet. A-F, L: Upper lingual hemispheroidal

939 molariform. Note the central depression in teeth photographed in A-C and F. A-C

940 (DBUA-F 165-1); D-E (LAQ, not numbered); F (DBUA-F 674). G-K: anterior teeth. G-H

941 (DBUA-F 667); I (DBUA-F 599); J-K (DBUA-F 477-2); L (MGM 11321). M-Q: Teeth of

942 Sparidae indet.; these specimens were collected by Georges Zbyszewski at Santa Maria

943 Island (no information for locality) and originally referred to Diplodus jomnitanus.

944 Original label by the former Serviços Geológicos de Portugal (presently housed at the 945 Museu Geológico e Mineiro, Lisbon: MGM 11313). M, P: Apical view of the teeth; N-O, 946 Q: Lateral view. [Intended for page width].

947

948 Figure 6. Actinopterygian fishes from Early Pliocene (DBUA-F 825, 1069, 1214) and Late 949 Pleistocene (Last Interglacial, MIS 5e; DBUA-F 1030) deposits of Santa Maria Island 950 (Azores). A: Lower grinding face view of Early Pliocene fragmentary tooth plate (DBUA951 F 1069) of Sparisoma cretense. B-E: Upper grinding face view of pharyngeal plates of 952 Sparisoma cretense. B-C, E: Lower pharyngeal plates. B (DBUA-F 1030), C (DBUA-F 953 1214-1), E (DBUA-F 825). D: Upper pharyngeal plate (DBUA-F 1214-2). F-G: Upper 
954 grinding face view of recent pharyngeal plates from a dissected S. cretense. F: Upper

955 pharyngeal plate. G: Lower pharyngeal plate. [Intended for page width].

956

957 Figure 7. Actinopterygian fishes from Early Pliocene deposits of Santa Maria Island

958 (Azores). A-G: Labrodon pavimentatum Gervais, 1857. A-E: Fragmentary pharyngeal

959 plates collected at Pedra-que-pica outcrop (B, D: DBUA-F 678; C, E: DBUA-F 386); F-G:

960 Fragmentary pharyngeal plate collected at Santa Maria (no locality; MGM 11318). C, D,

961 F: Upper grinding face view of lower pharyngeal plate. E, G: Lower grinding face view

962 of lower pharyngeal plate. [Intended for page width].

963

964 Figure 8. A-C: NE Atlantic Biogeographic Molluscan Provinces from late Miocene to

965 Pliocene (A, 6.0-5.33 Ma), early Pliocene to the end of the mid-Piacenzian Warm

966 Period (B, 5.33-2.95 Ma) and the present (C) (Ávila et al., 2016). D-F: Comparison of

967 large-scale evolutionary and biogeographical patterns, as a result of long-distance

968 dispersal of marine species between oceanic islands located at different climate

969 settings (subtropical versus temperate latitudes) for the last $150 \mathrm{kyr}$, encompassing the

970 Last Interglacial (MIS 5e), the Last Glacial episode, and the present interglacial ${ }^{6}$. D:

971 During the final phase of Termination 2 and/or the beginning of the Last Interglacial, a

972 subset of marine subtropical species expands their geographical ranges towards higher

973 latitudes (red arrow), reaching temperate archipelagos and establishing viable

974 populations in those islands (e.g. small red star in D). In a similar way, a subset of

975 marine temperate species expands their geographical ranges towards higher latitudes,

976 reaching boreal/arctic archipelagos and establishing viable populations as well (blue

977 arrow). E: During the course of the Last Glacial episode, the thermophilic species that 
978 established on temperate islands are extirpated and it is expected that a subset of

979 marine temperate species (small blue circles), adapted to cool temperatures may

980 expand their geographical ranges towards lower latitudes, reaching subtropical

981 archipelagos and establishing viable populations. F: the subsequent episode of global

982 warming that led to the present interglacial, extirpates the cold-adapted species that

983 reached subtropical islands during the previous glacial episode, and range expansion of

984 species towards higher latitudes is documented. G-I: Mobile sediment response to

985 glacio-eustatic sea level fluctuations (Ávila et al., 2008b, 2010). G: During the Last

986 interglacial (MIS 5e), as a result of marine and fluvial erosion, sediments are

987 transported to the island shelf where they accumulate between the shoreline angle

988 (i.e., the angle between the cliff of the island and the shore platform) and the erosive

989 shelf edge. $\mathbf{H}$ : The inception of sea-level lowstands during the Last Glacial episode,

990 promotes the remobilization and transport downslope of sediments from the island

991 shelf, when relative mean sea level falls below the erosive shelf edge. Whenever this

992 happens, sediments are lost to the abyssal depths that surround the insular edifice. I:

993 Sediments accumulate again on the island shelf, as a result of marine and fluvial

994 erosion, during the present sea-level highstand. [Intended for page width].

995

996

997 


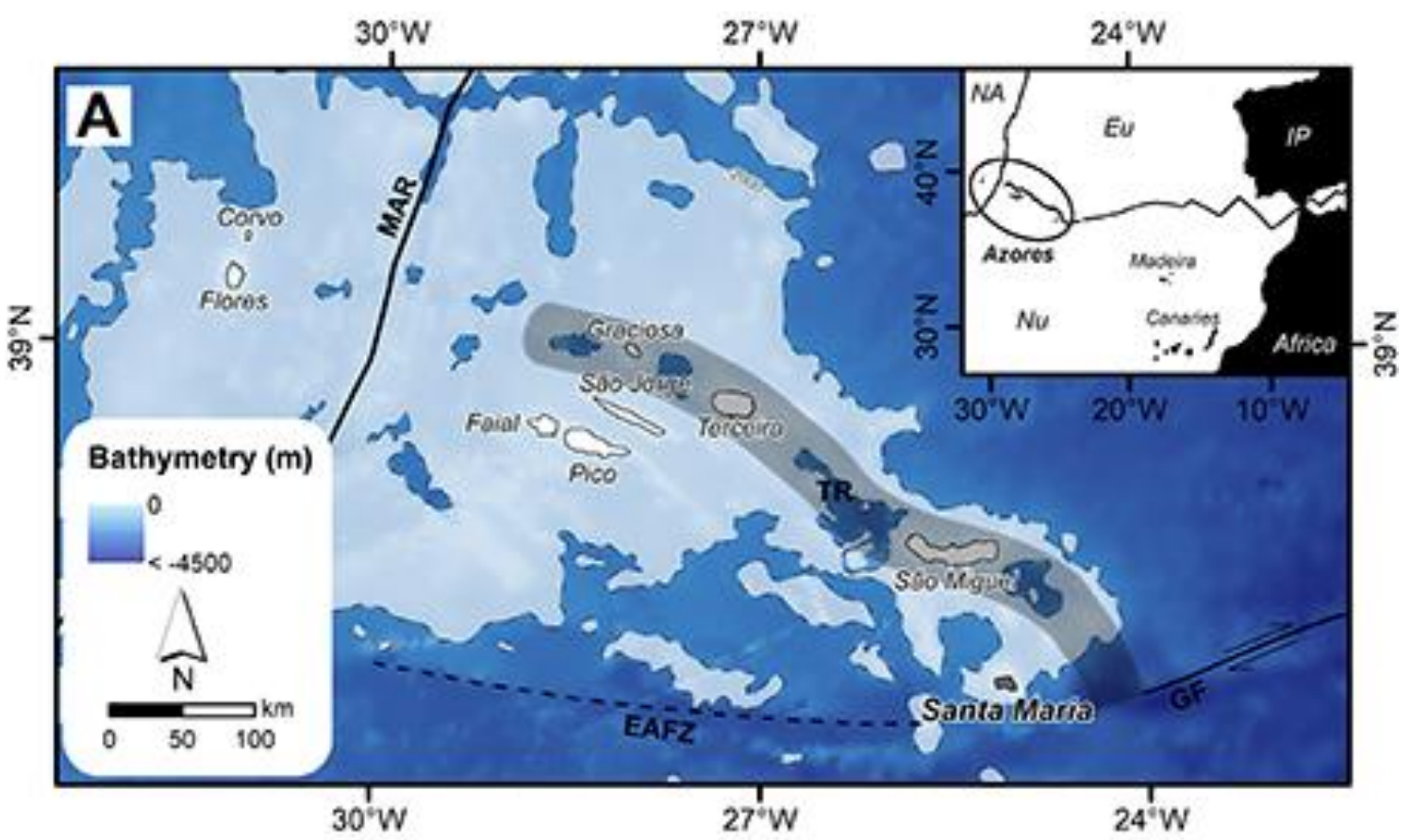

B

999

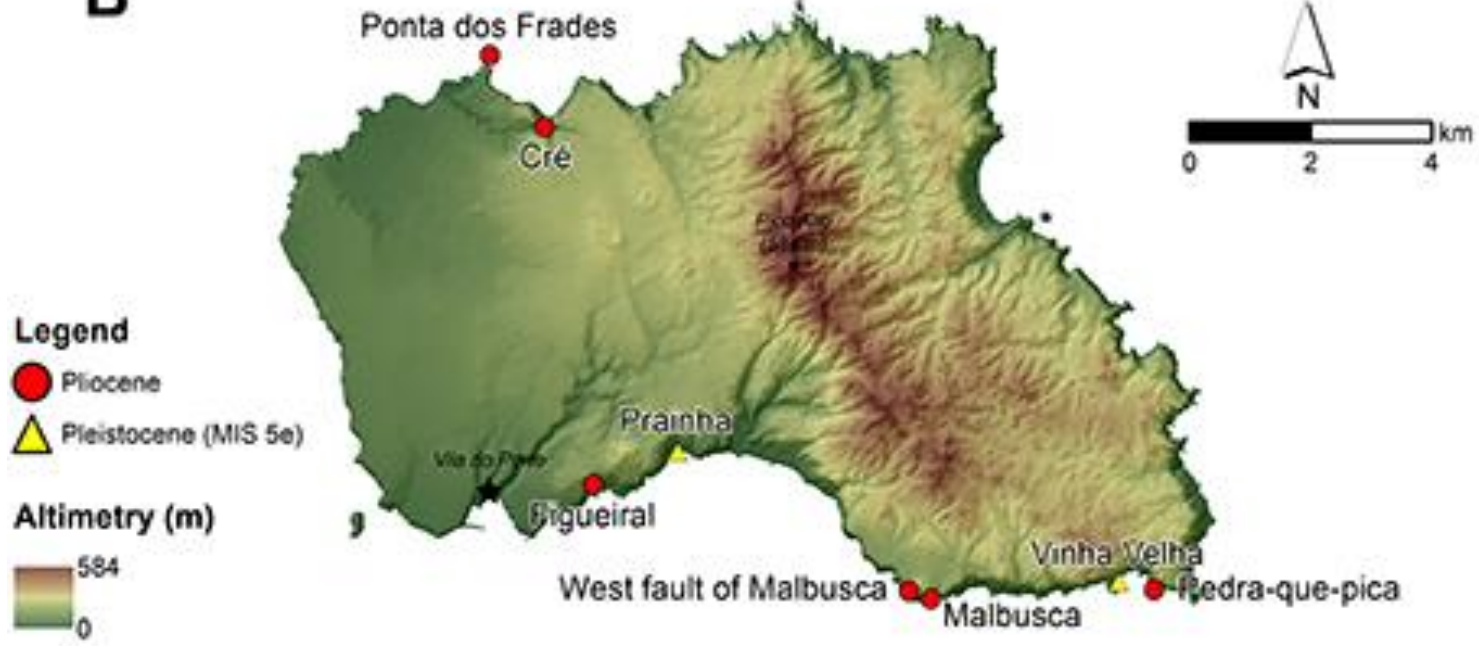

1000 Figure 1. A: Location of the Azores Archipelago in the NE Atlantic, and location and

1001 geotectonic setting of Santa Maria Island within the Azores Archipelago and within the

1002 Azores triple junction, respectively. The light blue area represents the Azores plateau

1003 (see text). MAR: Mid-Atlantic Ridge; EAFZ: East Azores fault zone; GF: Gloria fault; NA:

1004 North American plate; Eu: Eurasian plate; Nu: Nubian (African) plate. B: location of the

1005 Pliocene (red circles) and Pleistocene fossiliferous outcrops (yellow triangles) of Santa

1006 Maria Island. The Pleistocene outcrops are restricted to the warmest interval of the 
1007 Last Interglacial Period (c. 116-130 kyr), which is known as MIS 5e (Marine Isotopic

1008 Substage 5e). [Intended for page width].

1009

1010 

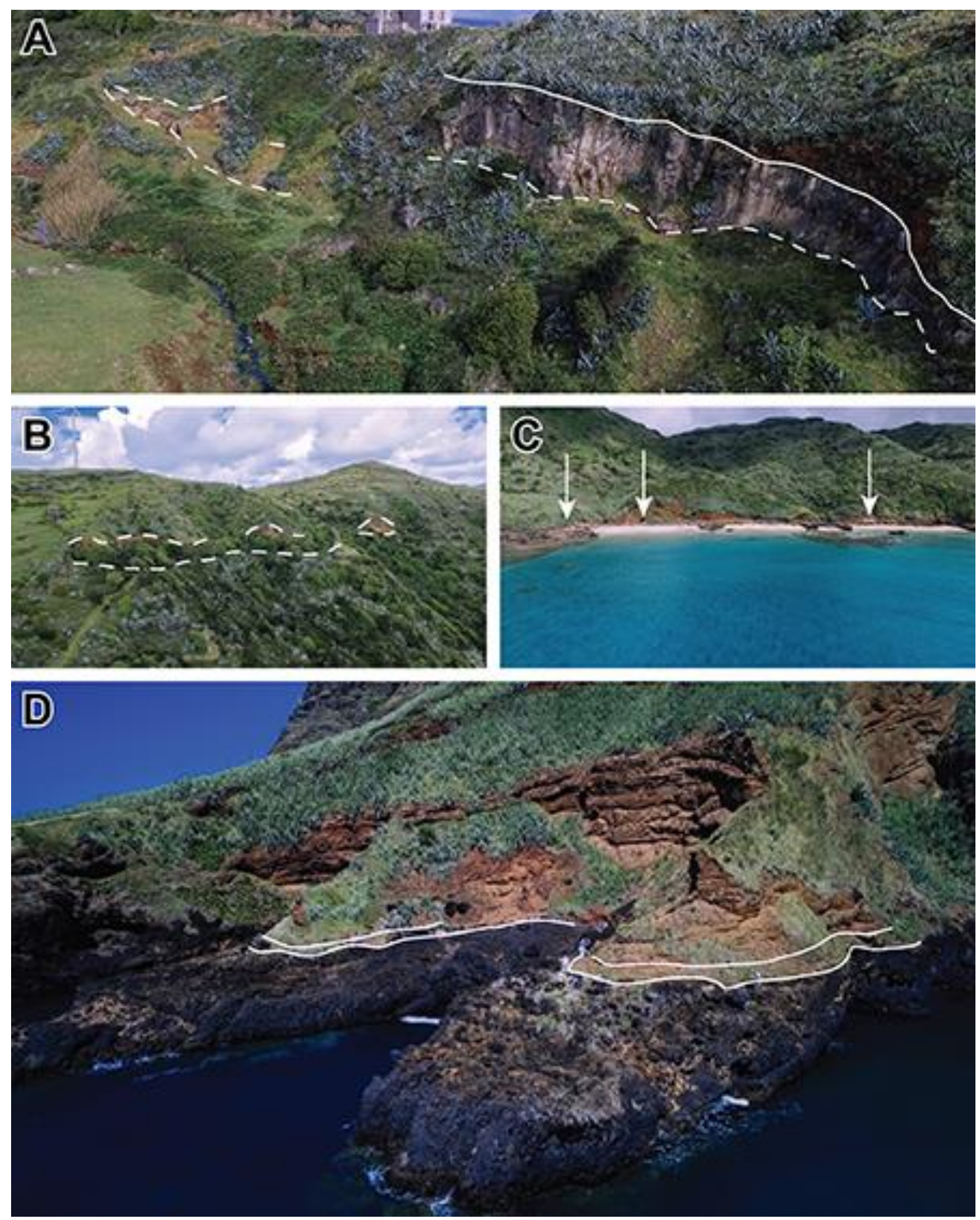

1012 Figure 2. Aerial (drone) views of the fossiliferous outcrops from Santa Maria Island. A-

1013 B: Pliocene outcrops; C-D: Pleistocene (MIS 5e) outcrops. The white line delimits the

1014 outcrops. A: Cré. B: Figueiral. C: Prainha (the white arrows point to the areas where

1015 fossiliferous sediments are better preserved). D: Vinha Velha. [Intended for page

1016 width]. 

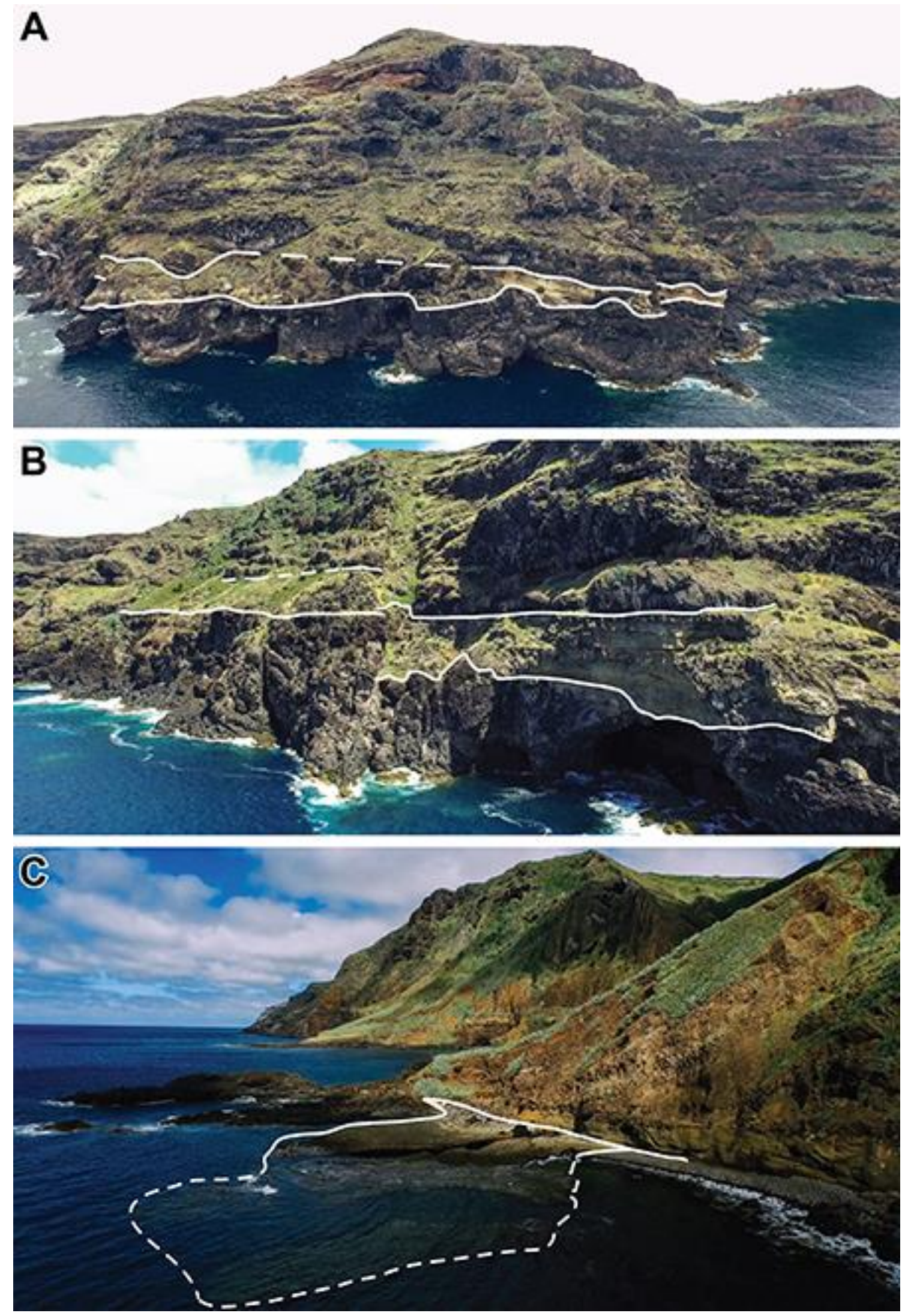

1018 Figure 3. Aerial (drone) views of the Pliocene fossiliferous outcrops from Santa Maria

1019 Island. The white line delimits the outcrops. A: Malbusca. B: West fault of Malbusca. C: 
1020 Pedra-que-pica. At West fault of Malbusca (B), the fossil strata are displaced by a fault

1021 slip of about $20 \mathrm{~m}$. Pedra-que-pica (C) is probably the largest worldwide multispecific

1022 coquina ever described from a volcanic oceanic island, with a total estimated area of

$1023>23,400 \mathrm{~m}^{2}$ and a total thickness for the sediments of 10-11 m (Ávila et al., 2015b).

1024 [Intended for page width].

1025

1026 


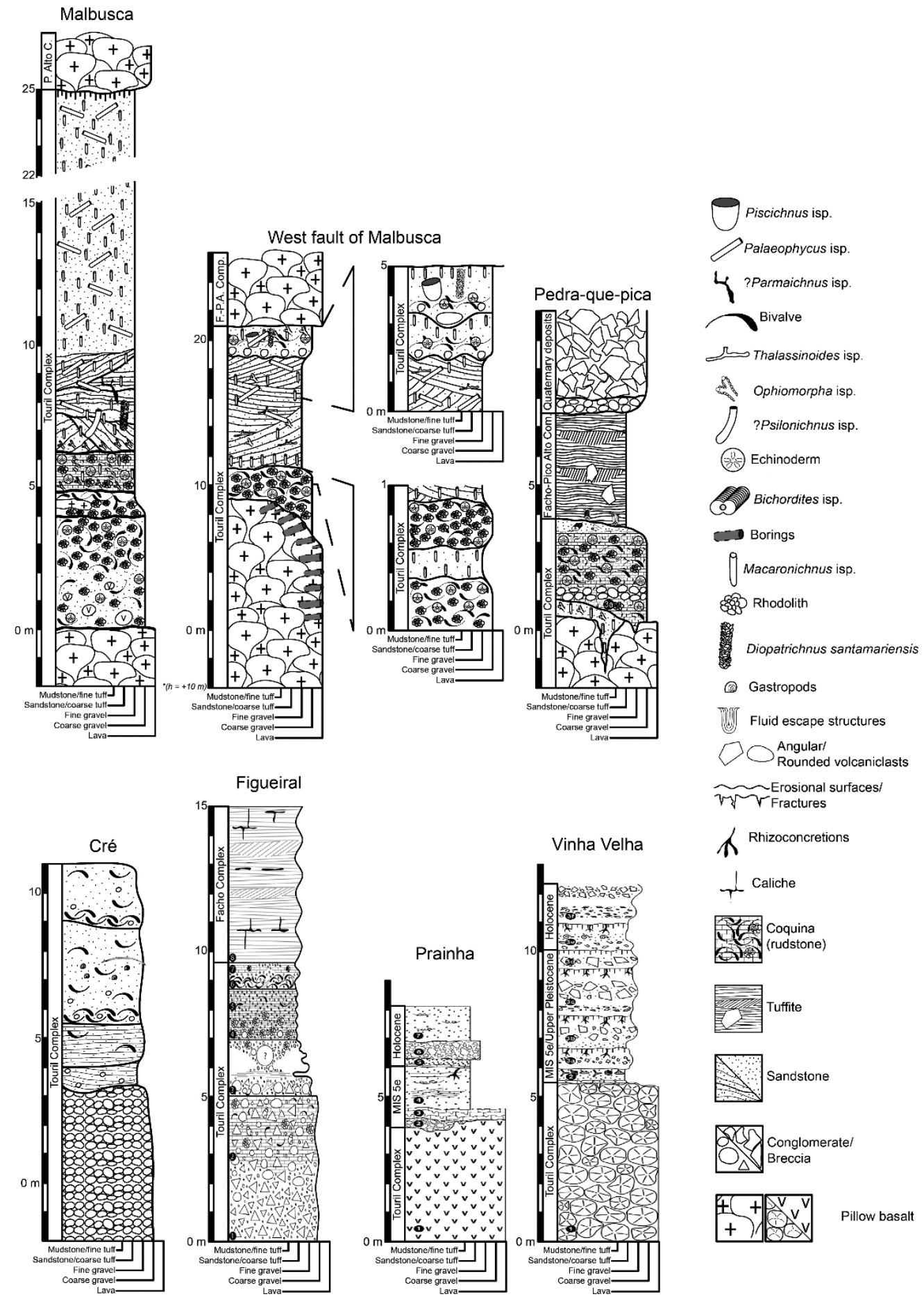

1028 Figure 4. Stratigraphic columns of the studied outcrops: Malbusca (Rebelo et al.,

1029 2016a; Uchman et al., 2017), Figueiral (Ávila et al., 2018), Pedra-que-pica (Ávila et al.,

1030 2015b), West fault of Malbusca (Uchman et al., 2017), Cré (Janssen et al., 2008),

1031 Prainha and Vinha Velha (Ávila et al., 2010, 2015a). [Intended for page width]. 


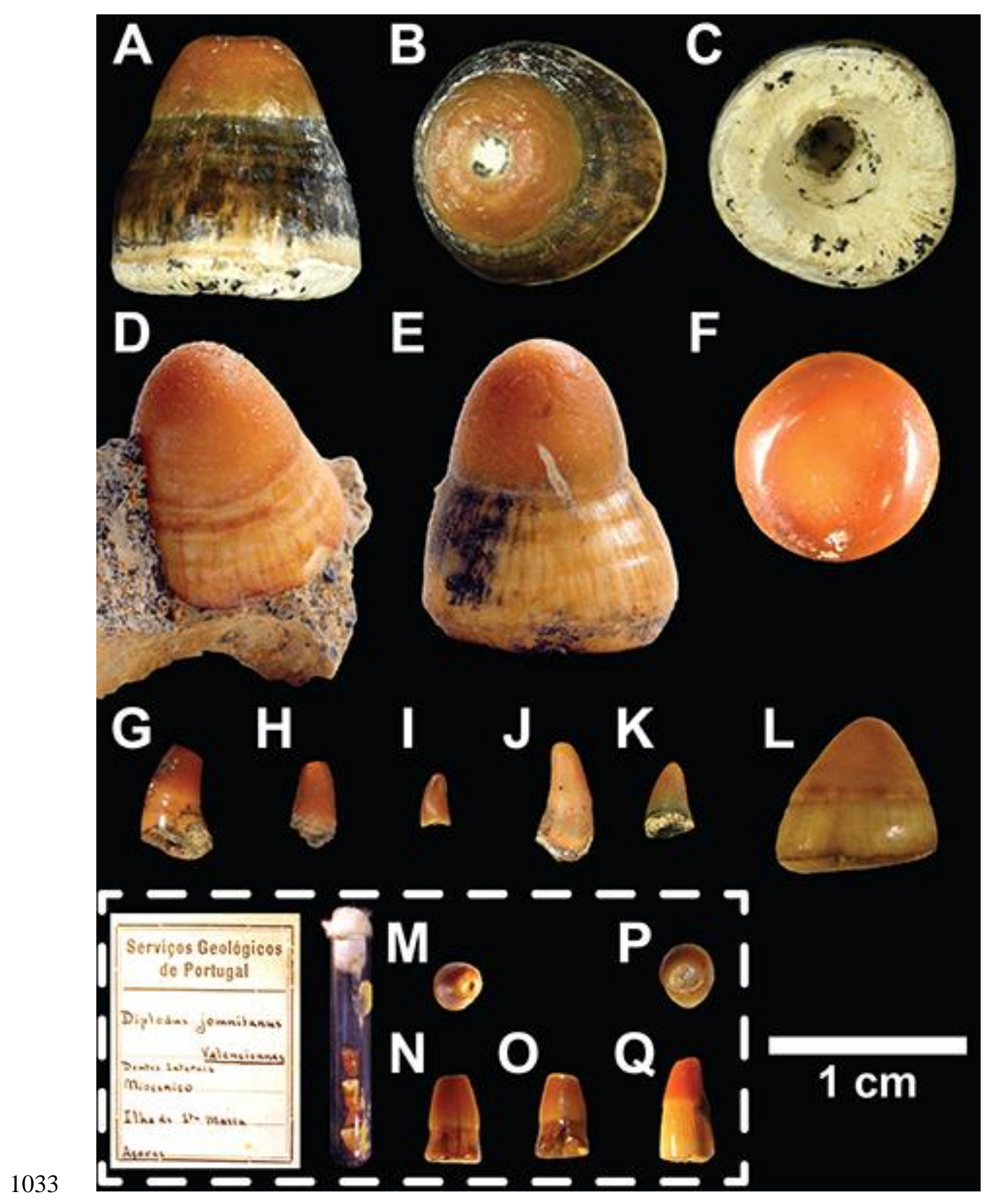

1034 Figure 5. Actinopterygian fishes from Early Pliocene deposits of Santa Maria Island

1035 (Azores). A-L: Teeth of Sparidae indet. A-F, L: Upper lingual hemispheroidal

1036 molariform. Note the central depression in teeth photographed in A-C and F. A-C

1037 (DBUA-F 165-1); D-E (LAQ, not numbered); F (DBUA-F 674). G-K: anterior teeth. G-H 
1038 (DBUA-F 667); I (DBUA-F 599); J-K (DBUA-F 477-2); L (MGM 11321). M-Q: Teeth of

1039 Sparidae indet.; these specimens were collected by Georges Zbyszewski at Santa Maria

1040 Island (no information for locality) and originally referred to Diplodus jomnitanus.

1041 Original label by the former Serviços Geológicos de Portugal (presently housed at the

1042 Museu Geológico e Mineiro, Lisbon: MGM 11313). M, P: Apical view of the teeth; N-O,

1043 Q: Lateral view. [Intended for page width].

1044

1045 


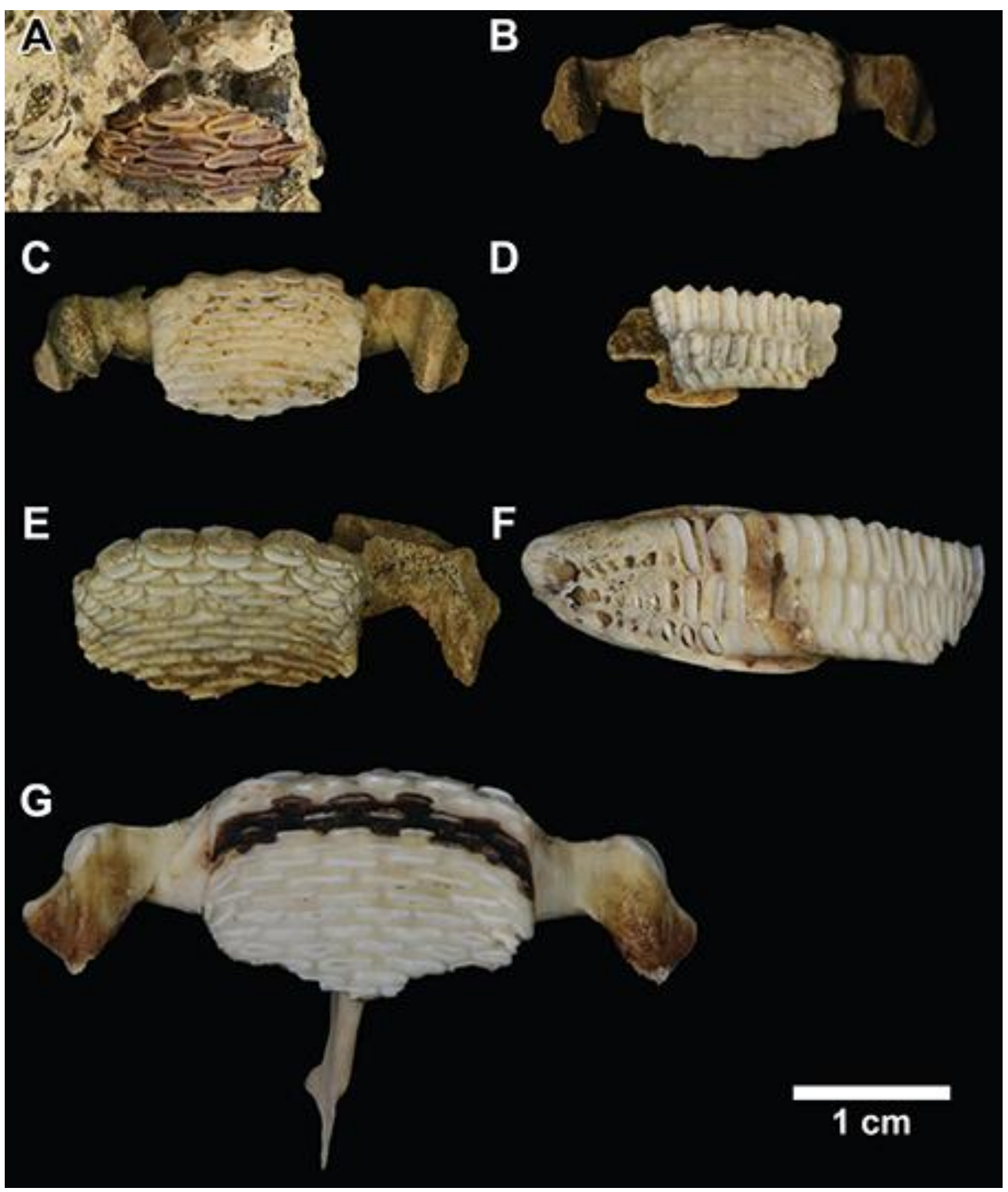

1047 Figure 6. Actinopterygian fishes from Early Pliocene (DBUA-F 825, 1069, 1214) and Late

1048 Pleistocene (Last Interglacial, MIS 5e; DBUA-F 1030) deposits of Santa Maria Island

1049 (Azores). A: Lower grinding face view of Early Pliocene fragmentary tooth plate (DBUA-

1050 F 1069) of Sparisoma cretense. B-E: Upper grinding face view of pharyngeal plates of

1051 Sparisoma cretense. B-C, E: Lower pharyngeal plates. B (DBUA-F 1030), C (DBUA-F

1052 1214-1), E (DBUA-F 825). D: Upper pharyngeal plate (DBUA-F 1214-2). F-G: Upper 
1053 grinding face view of recent pharyngeal plates from a dissected S. cretense. F: Upper

1054 pharyngeal plate. G: Lower pharyngeal plate. [Intended for page width].

1055

1056 

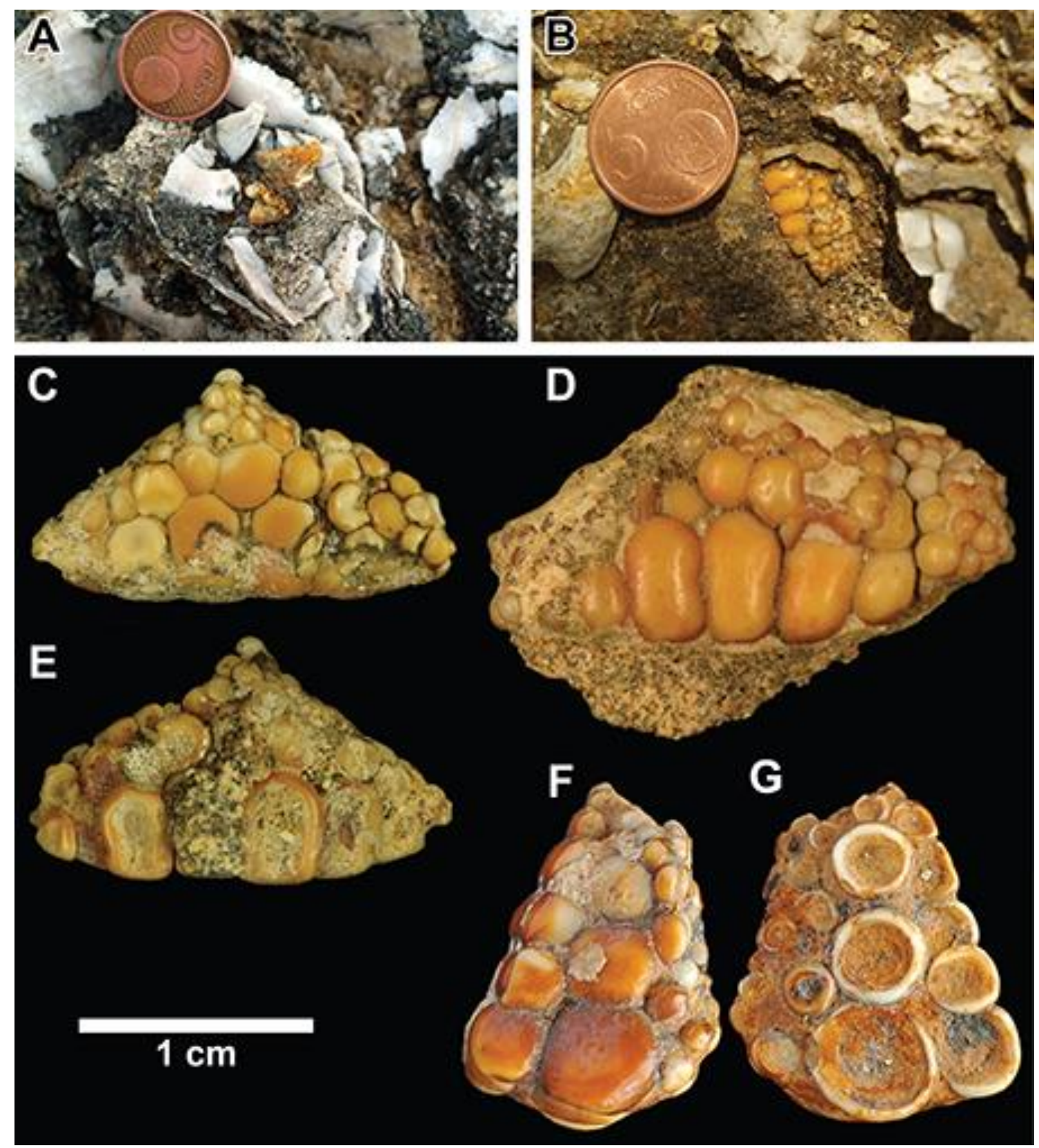

1057

1058 Figure 7. Actinopterygian fishes from Early Pliocene deposits of Santa Maria Island

1059 (Azores). A-G: Labrodon pavimentatum Gervais, 1857. A-E: Fragmentary pharyngeal

1060 plates collected at Pedra-que-pica outcrop (B, D: DBUA-F 678; C, E: DBUA-F 386); F-G:

1061 Fragmentary pharyngeal plate collected at Santa Maria (no locality; MGM 11318). C, D,

1062 F: Upper grinding face view of lower pharyngeal plate. E, G: Lower grinding face view

1063 of lower pharyngeal plate. [Intended for page width]. 


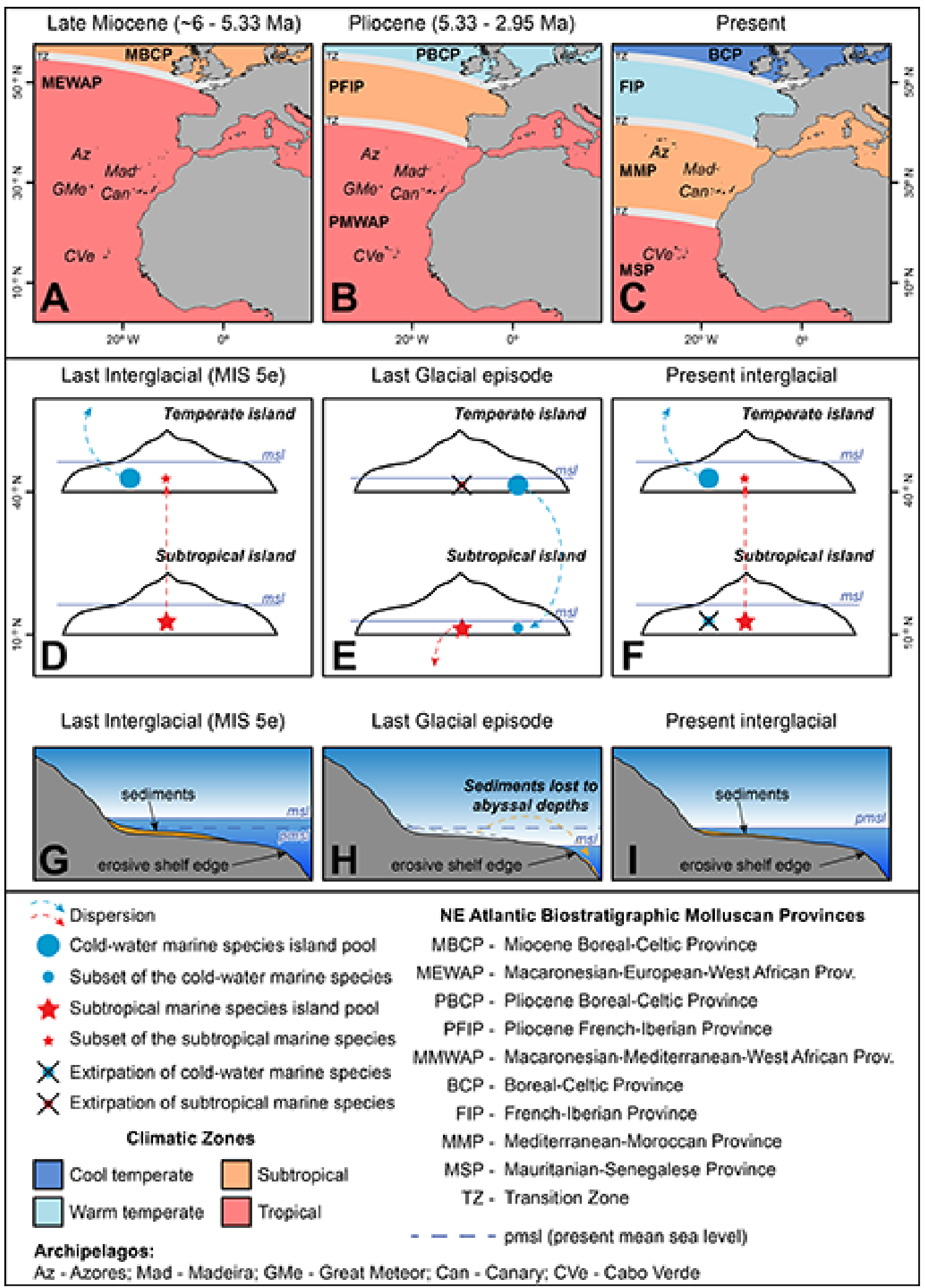

1066 Figure 8. A-C: NE Atlantic Biogeographic Molluscan Provinces from late Miocene to

1067 Pliocene (A, 6.0-5.33 Ma), early Pliocene to the end of the mid-Piacenzian Warm

1068 Period (B, 5.33-2.95 Ma) and the present (C) (Ávila et al., 2016). D-F: Comparison of 
1069 large-scale evolutionary and biogeographical patterns, as a result of long-distance

1070 dispersal of marine species between oceanic islands located at different climate

1071 settings (subtropical versus temperate latitudes) for the last $150 \mathrm{kyr}$, encompassing the

1072 Last Interglacial (MIS 5e), the Last Glacial episode, and the present interglacial (Ávila et

1073 al., 2019). D: During the final phase of Termination 2 and/or the beginning of the Last

1074 Interglacial, a subset of marine subtropical species expands their geographical ranges

1075 towards higher latitudes (red arrow), reaching temperate archipelagos and

1076 establishing viable populations in those islands (e.g. small red star in D). In a similar

1077 way, a subset of marine temperate species expands their geographical ranges towards

1078 higher latitudes, reaching boreal/arctic archipelagos and establishing viable

1079 populations as well (blue arrow). E: During the course of the Last Glacial episode, the

1080 thermophilic species that established on temperate islands are extirpated and it is

1081 expected that a subset of marine temperate species (small blue circles), adapted to

1082 cool temperatures may expand their geographical ranges towards lower latitudes,

1083 reaching subtropical archipelagos and establishing viable populations. F: the

1084 subsequent episode of global warming that led to the present interglacial, extirpates

1085 the cold-adapted species that reached subtropical islands during the previous glacial

1086 episode, and range expansion of species towards higher latitudes is documented. G-I:

1087 Mobile sediment response to glacio-eustatic sea level fluctuations (Ávila et al., 2008b,

1088 2010). G: During the Last interglacial (MIS 5e), as a result of marine and fluvial erosion,

1089 sediments are transported to the island shelf where they accumulate between the

1090 shoreline angle (i.e., the angle between the cliff of the island and the shore platform)

1091 and the erosive shelf edge. $\mathbf{H}$ : The inception of sea-level lowstands during the Last

1092 Glacial episode, promotes the remobilization and transport downslope of sediments 
1093 from the island shelf, when relative mean sea level falls below the erosive shelf edge.

1094 Whenever this happens, sediments are lost to the abyssal depths that surround the

1095 insular edifice. I: Sediments accumulate again on the island shelf, as a result of marine

1096 and fluvial erosion, during the present sea-level highstand. [Intended for page width].

1097 
Table 1. Relative age of the outcrops (in millions of years) from Santa Maria Island (Azores) containing fossil remains of Actinopterygii fishes.

\begin{tabular}{|c|c|c|c|c|c|c|}
\hline \multirow[b]{2}{*}{ Outcrop } & \multirow{2}{*}{$\begin{array}{l}\text { Age } \\
\text { (Ma) }\end{array}$} & \multirow[b]{2}{*}{ Bed } & \multirow{2}{*}{$\begin{array}{l}\text { Inferred depth of } \\
\text { deposition (m) }\end{array}$} & \multicolumn{3}{|c|}{ Number of teeth/pharyngeal plates per species } \\
\hline & & & & Sparidae & $\begin{array}{c}\text { Sparisoma } \\
\text { cretense }\end{array}$ & $\begin{array}{c}\text { Labrodon } \\
\text { pavimentatum }\end{array}$ \\
\hline Cré & $4.78 \pm 0.13$ to $4.13 \pm 0.19$ & Sandstone & ? & 4 & & \\
\hline Figueiral & $4.78 \pm 0.13$ to $4.13 \pm 0.19$ & Sandstone & ? & 1 & & \\
\hline Ponta dos Frades & $4.78 \pm 0.13$ to $4.13 \pm 0.19$ & Sandstone & ? & & 6 & \\
\hline Pedra-que-pica & $4.78 \pm 0.13$ to $4.13 \pm 0.19$ & Coquina & -40 & 26 & 1 & 2 \\
\hline Malbusca & $4.32 \pm 0.06$ to $4.02 \pm 0.06$ & Sandstone & -60 & 17 & & \\
\hline West fault of Malbusca & $4.32 \pm 0.06$ to $4.02 \pm 0.06$ & Sandstone & -60 & 2 & & \\
\hline Vinha Velha & Last Interglacial (MIS 5e) & Sand & +1 to +2 & & 1 & \\
\hline
\end{tabular}


Table 2. Present geographical distribution of the genus Sparisoma in the Atlantic Ocean and the Mediterranean Sea. AZO - Azores Archipelago;

1102 MAD - Madeira Archipelago; SEL - Selvagens Archipelago; CAN - Canaries Archipelago; CAB - Cabo Verde Archipelago; STP - São Tomé and

1103 Príncipe Archipelago; IBE - Atlantic Iberian shores from Finisterra south to the Straits of Gibraltar; MED - Mediterranean Sea; TWAF - Tropical

1104 west African shores, from Cape Blanc (Senegal) south to Angola; NWA - Atlantic coast of Northwest Africa, from the Straits of Gibraltar south

1105 to Senegal; ASC - Ascension Island; STH - Saint Helena Island; SWA - Southwest Atlantic, including Brazil and its oceanic islands; WAT -

1106 Western Atlantic, including the Caribbean Sea.

\begin{tabular}{|c|c|c|c|c|c|c|c|c|c|c|c|c|c|c|}
\hline Species & AZO & MAD & SEL & CAN & CAB & STP & IBE & MED & TWAF & NWA & ASC & STH & SWA & WAT \\
\hline Sparisoma choati & 0 & 0 & 0 & 0 & 1 & 1 & 0 & 0 & 1 & 0 & 0 & 0 & 0 & 0 \\
\hline Sparisoma cretense & 1 & 1 & 1 & 1 & 1 & 0 & 1 & 1 & 1 & 1 & 0 & 0 & 0 & 0 \\
\hline Sparisoma frondosum & 0 & 0 & 0 & 0 & 1 & 0 & 0 & 0 & 0 & 0 & 0 & 0 & 0 & 0 \\
\hline Sparisoma amplum & 0 & 0 & 0 & 0 & 0 & 0 & 0 & 0 & 0 & 0 & 0 & 0 & 1 & 0 \\
\hline Sparisoma atomarium & 0 & 0 & 0 & 0 & 0 & 0 & 0 & 0 & 0 & 0 & 0 & 0 & 0 & 1 \\
\hline Sparisoma aurofrenatum & 0 & 0 & 0 & 0 & 0 & 0 & 0 & 0 & 0 & 0 & 0 & 0 & 0 & 1 \\
\hline Sparisoma axillare & 0 & 0 & 0 & 0 & 0 & 0 & 0 & 0 & 0 & 0 & 0 & 0 & 1 & 0 \\
\hline Sparisoma chrysopterum & 0 & 0 & 0 & 0 & 0 & 0 & 0 & 0 & 0 & 0 & 0 & 0 & 0 & 1 \\
\hline Sparisoma griseorubrum & 0 & 0 & 0 & 0 & 0 & 0 & 0 & 0 & 0 & 0 & 0 & 0 & 0 & 1 \\
\hline Sparisoma radians & 0 & 0 & 0 & 0 & 0 & 0 & 0 & 0 & 0 & 0 & 0 & 0 & 1 & 1 \\
\hline Sparisoma rocha & 0 & 0 & 0 & 0 & 0 & 0 & 0 & 0 & 0 & 0 & 0 & 0 & 1 & 0 \\
\hline Sparisoma rubripinne & 0 & 0 & 0 & 0 & 0 & 0 & 0 & 0 & 0 & 0 & 0 & 0 & 0 & 1 \\
\hline Sparisoma strigatum & 0 & 0 & 0 & 0 & 0 & 0 & 0 & 0 & 0 & 0 & 1 & 1 & 0 & 0 \\
\hline Sparisoma tuiupiranga & 0 & 0 & 0 & 0 & 0 & 0 & 0 & 0 & 0 & 0 & 0 & 0 & 1 & 0 \\
\hline Sparisoma viride & 0 & 0 & 0 & 0 & 0 & 0 & 0 & 0 & 0 & 0 & 0 & 0 & 1 & 1 \\
\hline
\end{tabular}


1108 Table 3. Taxa/species reported from the Pliocene sediments of Santa Maria Island and

1109 that are presently extinct or were extirpated (local disappearances) from the marine

1110 fauna of the island during the global climate deterioration that characterizes the late

1111 Pliocene.

\begin{tabular}{|c|c|c|}
\hline Phylum & Taxa & Status \\
\hline \multirow[t]{11}{*}{ Mollusca } & Aequipecten macrotis (Sowerby, 1847) & extinct \\
\hline & Gigantopecten latissimus (Brocchi, 1814 & extinct \\
\hline & Chlamys hartungi (Mayer, 1864) & extinct \\
\hline & Lopha plicatuloides (Mayer, 1864) & extinct \\
\hline & Pecten dunkeri Mayer, 1864 & extinct \\
\hline & Persististrombus coronatus (Defrance, 1827) & extinct \\
\hline & Janthina typica (Brönn, 1861) & extinct \\
\hline & Cavolinia grandis (Bellardi, 1873) & extinct \\
\hline & Cavolinia marginata (Brönn, 1862) & extinct \\
\hline & Cuvierina intermedia (Bellardi, 1873) & extinct \\
\hline & Bowdenatheca jamaicensis Collins, 1934 & extinct \\
\hline \multirow[t]{6}{*}{ Echinodermata } & Clypeaster altus (Leske, 1778) & extinct \\
\hline & & local \\
\hline & Eucidaris tribuloides (Lamarck, 1816) & disappearance \\
\hline & & local \\
\hline & Echinoneus cf. cyclostomus Leske, 1778 & disappearance \\
\hline & Schizobrissus sp. & extinct \\
\hline Brachiopoda & Novocrania turbinata (Poli, 1795) & extinct \\
\hline
\end{tabular}


Table 3. (Continued)

Arthropoda

(Crustacea)

Chordata

(Elasmobranchii)

Notorynchus primigenius (Agassiz, 1833)

extinct

Carcharias acutissima (Agassiz, 1833),

Cosmopolitodus hastalis (Agassiz, 1833),

Paratodus benedenii (Le Hon, 1871),

Megaselachus megalodon (Agassiz in Charlesworth,

1837)

Chordata

(Actinopterygii)

Sparidae indet.

Labrodon pavimentatum Gervais, 1857 extinct

extinct

extinct

extinct

extinct

extinct

extinct

1112

1113 